\title{
Zoonotic Diseases: Etiology, Impact, and Control
}

\author{
Md. Tanvir Rahman ${ }^{1, *} \mathbb{1}$, Md. Abdus Sobur ${ }^{1} \mathbb{D}$, Md. Saiful Islam ${ }^{1} \mathbb{C}$, Samina Ievy ${ }^{1}$, \\ Md. Jannat Hossain ${ }^{1}$, Mohamed E. El Zowalaty ${ }^{2,3}$, AMM Taufiquer Rahman ${ }^{4}$ \\ and Hossam M. Ashour ${ }^{5,6, *}$ \\ 1 Department of Microbiology and Hygiene, Faculty of Veterinary Science, \\ Bangladesh Agricultural University, Mymensingh 2202, Bangladesh; soburvetbau@gmail.com (M.A.S.); \\ dvm41257@bau.edu.bd (M.S.I.); v.samina@gmail.com (S.I.); md.jannat.hossain@gmail.com (M.J.H.) \\ 2 Department of Clinical Sciences, College of Medicine, University of Sharjah, Sharjah 27272, UAE; \\ elzow005@gmail.com \\ 3 Zoonosis Science Center, Department of Medical Biochemistry and Microbiology, Uppsala University, \\ SE 75123 Uppsala, Sweden \\ 4 Adhunik Sadar Hospital, Naogaon 6500, Bangladesh; drtaufiqurahman@gmail.com \\ 5 Department of Integrative Biology, College of Arts and Sciences, University of South Florida, \\ St. Petersburg, FL 33701, USA \\ 6 Department of Microbiology and Immunology, Faculty of Pharmacy, Cairo University, Cairo 11562, Egypt \\ * Correspondence: tanvirahman@bau.edu.bd (M.T.R.); hossamking@mailcity.com (H.M.A.)
}

Received: 12 August 2020; Accepted: 2 September 2020; Published: 12 September 2020

\begin{abstract}
Most humans are in contact with animals in a way or another. A zoonotic disease is a disease or infection that can be transmitted naturally from vertebrate animals to humans or from humans to vertebrate animals. More than $60 \%$ of human pathogens are zoonotic in origin. This includes a wide variety of bacteria, viruses, fungi, protozoa, parasites, and other pathogens. Factors such as climate change, urbanization, animal migration and trade, travel and tourism, vector biology, anthropogenic factors, and natural factors have greatly influenced the emergence, re-emergence, distribution, and patterns of zoonoses. As time goes on, there are more emerging and re-emerging zoonotic diseases. In this review, we reviewed the etiology of major zoonotic diseases, their impact on human health, and control measures for better management. We also highlighted COVID-19, a newly emerging zoonotic disease of likely bat origin that has affected millions of humans along with devastating global consequences. The implementation of One Health measures is highly recommended for the effective prevention and control of possible zoonosis.
\end{abstract}

Keywords: zoonosis; pathogens; viruses; bacteria; fungi; animal; SARS-CoV-2; COVID-19; one health; prevention

\section{Introduction}

Humans, animals, and the environment play a significant role in the emergence and transmission of different infectious diseases [1]. Most of the infectious diseases affecting humans are of animal origin. The "Asia Pacific strategy for emerging diseases: 2010" report estimated that around 60\% of the emerging human infections are zoonotic in nature and among these pathogens more than $70 \%$ originated from wildlife species [2]. The newly emerged diseases in humans in recent decades were of animal origin and were directly associated with animal origin foods [3].

The term "Zoonoses" is derived from the Greek word "Zoon", which means animal, and "nosos", which means illness. According to the World Health Organization (WHO), any disease or infection that is naturally transmissible from vertebrate animals to humans or from humans to animals is classified as a zoonosis [4]. Among the human pathogens, about $61 \%$ are zoonotic in nature [5]. 
Zoonoses is a great public health concern and a direct human health hazard that may even lead to death. Across the globe, the 13 most common zoonoses were most impactful on poor livestock workers in low- and middle-income countries and have caused an estimated 2.4 billion cases of illness and 2.7 million deaths in humans per year in addition to their negative effect on human health [6]. Most of these diseases affect animal health and decrease livestock production [6].

\section{Classification of Zoonoses}

Zoonotic diseases are caused by a wide range of pathogens. Based on etiology, zoonoses are classified into bacterial zoonoses (such as anthrax, salmonellosis, tuberculosis, Lyme disease, brucellosis, and plague), viral zoonoses (such as rabies, acquired immune deficiency syndrome- AIDS, Ebola, and avian influenza), parasitic zoonoses (such as trichinosis, toxoplasmosis, trematodosis, giardiasis, malaria, and echinococcosis), fungal zoonoses (such as ring worm), rickettsial zoonoses (Q-fever), chlamydial zoonoses (psittacosis), mycoplasma zoonoses (Mycoplasma pneumoniae infection), protozoal zoonoses, and diseases caused by acellular non-viral pathogenic agents (such as transmissible spongiform encephalopathies and mad cow disease) [7]. Table 1 lists the major zoonotic diseases with their etiological agents, animal host, and major symptoms.

Table 1. Major Zoonotic Diseases, their etiological agents, hosts, and the major symptoms in humans.

\begin{tabular}{|c|c|c|c|}
\hline Disease & Etiology & Animal Host & $\begin{array}{c}\text { Major Symptoms, System or } \\
\text { Organs Involved }\end{array}$ \\
\hline \multicolumn{4}{|c|}{ Bacterial zoonoses } \\
\hline Anthrax & Bacillus anthracis & $\begin{array}{l}\text { Cattle, horses, sheep, } \\
\text { pigs, dogs, bison, elks, } \\
\text { white-tailed deer, goats, } \\
\text { and mink }\end{array}$ & $\begin{array}{c}\text { Skin, respiratory organs, or GI } \\
\text { tract }\end{array}$ \\
\hline Tuberculosis & $\begin{array}{l}\text { Mycobacterium bovis, } \\
\text { Mycobacterium caprae, } \\
\text { Mycobacterium microti }\end{array}$ & $\begin{array}{l}\text { Cattle, sheep, swine, } \\
\text { deer, wild boars, camels, } \\
\text { and bison }\end{array}$ & $\begin{array}{l}\text { Respiratory organs bone } \\
\text { marrow }\end{array}$ \\
\hline Brucellosis & $\begin{array}{l}\text { Brucella abortus } \\
\text { Brucella melitensis, } \\
\text { Brucella suis, } \\
\text { Brucella canis, }\end{array}$ & $\begin{array}{l}\text { Cattle, goats, sheep, pigs, } \\
\text { and dogs }\end{array}$ & $\begin{array}{l}\text { Fever, usually high in the } \\
\text { afternoon, back pain, joint } \\
\text { pain, poor appetite, and } \\
\text { weight loss }\end{array}$ \\
\hline Bubonic plague & Yersinia pestis & $\begin{array}{l}\text { Rock squirrels, wood } \\
\text { rats, ground squirrels, } \\
\text { prairie dogs, mice, voles, } \\
\text { chipmunks, and rabbits }\end{array}$ & $\begin{array}{l}\text { Fever, chills, abdominal pain, } \\
\text { diarrhea, vomiting, and } \\
\text { bleeding from natural opening }\end{array}$ \\
\hline Glanders & Burkholderia mallei & $\begin{array}{l}\text { Horses, donkeys, and } \\
\text { mules }\end{array}$ & $\begin{array}{l}\text { Fever, sweating, muscle aches, } \\
\text { chest pain, muscle tightness, } \\
\text { and headache }\end{array}$ \\
\hline Leprosy & Mycobacterium leprae & $\begin{array}{l}\text { Monkeys, rats, mice, and } \\
\text { cats }\end{array}$ & Skin lesions \\
\hline Leptospirosis & Leptospira interrogans & $\begin{array}{l}\text { Wild and domestic } \\
\text { animals including pet } \\
\text { dogs }\end{array}$ & $\begin{array}{l}\text { Fever, abdominal pain, } \\
\text { jaundice, and red eye }\end{array}$ \\
\hline Tularemia & Francisella tularensis & $\begin{array}{c}\text { Rabbits, squirrels, } \\
\text { muskrats, deer, sheep, } \\
\text { bull snakes, wild rodents, } \\
\text { beavers, cats, and dogs }\end{array}$ & $\begin{array}{l}\text { Joint pain, diarrhea, and dry } \\
\text { cough }\end{array}$ \\
\hline Arcobacter infections & $\begin{array}{c}\text { Arcobacter butzleri, } \\
\text { Arcobacter cryaerophilus, } \\
\text { Arcobacter skirrowii }\end{array}$ & $\begin{array}{l}\text { Cattle, sheep, pigs, and } \\
\text { chickens }\end{array}$ & $\begin{array}{l}\text { Abdominal pain, fever, and } \\
\text { vomiting }\end{array}$ \\
\hline
\end{tabular}


Table 1. Cont.

\begin{tabular}{|c|c|c|c|}
\hline Disease & Etiology & Animal Host & $\begin{array}{c}\text { Major Symptoms, System or } \\
\text { Organs Involved }\end{array}$ \\
\hline Actinomycosis & Actinomyces bovis & $\begin{array}{l}\text { Cattle, sheep, horses, } \\
\text { pigs, dogs, and other } \\
\text { mammals }\end{array}$ & $\begin{array}{l}\text { Swelling of lymph nodes, soft } \\
\text { tissues, skin, and abscess }\end{array}$ \\
\hline Bordetellosis & Bordetella bronchiseptica & Cats and dogs & Respiratory problem \\
\hline Lyme disease & Borrelia burgdorferi & Cats, dogs, and horses & $\begin{array}{l}\text { Fever, headache, skin rash, } \\
\text { and erythema migrans }\end{array}$ \\
\hline Campylobacter enteritis & $\begin{array}{l}\text { Campylobacter jejuni, } \\
\text { Campylobacter coli }\end{array}$ & $\begin{array}{l}\text { Cattle, sheep, chickens, } \\
\text { turkeys, dogs, cats, mink, } \\
\text { ferrets, and pigs }\end{array}$ & Enteric disorder \\
\hline $\begin{array}{l}\text { Campylobacter fetus } \\
\text { infection }\end{array}$ & $\begin{array}{l}\text { Campylobacter fetus subsp. } \\
\text { fetus, } \\
\text { Campylobacter fetus subsp. } \\
\text { testudinum }\end{array}$ & Cattle, sheep, and goats & Enteric disorder \\
\hline $\begin{array}{l}\text { Clostridioides difficile } \\
\text { infection }\end{array}$ & Clostridioides difficile & Cattle, horses, and birds & $\begin{array}{l}\text { Pseudomembranous colitis, } \\
\text { and diarrhea }\end{array}$ \\
\hline $\begin{array}{l}\text { Corynebacterium ulcerans } \\
\text { and Corynebacterium } \\
\text { pseudotuberculosis } \\
\text { infections }\end{array}$ & $\begin{array}{c}\text { Corynobacterium ulcerans, } \\
\text { Corynobacterium } \\
\text { pseudotuberculosis }\end{array}$ & Cattle, dogs, and cats & Diphtheria \\
\hline $\begin{array}{c}\text { Enterohemorrhagic } \\
\text { Escherichia coli infections }\end{array}$ & E coli O157:H7 & $\begin{array}{l}\text { Cattle, sheep, pigs, deer, } \\
\text { dogs, and poultry }\end{array}$ & $\begin{array}{c}\text { Enteritis and } \\
\text { Hemolytic-uremic syndrome } \\
\text { (HUS) }\end{array}$ \\
\hline Helicobacter infection & $\begin{array}{l}\text { Helicobacter pullorum, } \\
\text { Helicobacter suis }\end{array}$ & Poultry and pigs & Peptic ulcer \\
\hline Vibriosis & Vibrio parahaemolyticus & Farm animals & Enteritis \\
\hline Salmonellosis & $\begin{array}{l}\text { Salmonella enterica, } \\
\text { Salmonella bongor }\end{array}$ & $\begin{array}{l}\text { Domestic animals, birds, } \\
\text { and dogs }\end{array}$ & Enteritis \\
\hline Ehrlichiosis & $\begin{array}{c}\text { Anaplasma } \\
\text { phagocytophilum, } \\
\text { Ehrlichia ewingii, } \\
\text { Ehrlichia chaffeensis, } \\
\text { Ehrlichia canis, } \\
\text { Neorickettsia sennetsu }\end{array}$ & $\begin{array}{l}\text { Sheep, cattle, deer, dogs, } \\
\text { and cats }\end{array}$ & $\begin{array}{c}\text { Fever, headache, fatigue, } \\
\text { muscle aches, and occasionally } \\
\text { rash }\end{array}$ \\
\hline Pasteurellosis & Pasteurella multocida & $\begin{array}{l}\text { Poultry, pigs, cattle, } \\
\text { buffaloes, sheep, goats, } \\
\text { deer, cats, dogs, and } \\
\text { antelope }\end{array}$ & $\begin{array}{l}\text { Fever, vomiting, diarrhea, and } \\
\text { gangrene }\end{array}$ \\
\hline \multicolumn{4}{|c|}{ Viral zoonoses } \\
\hline Rabies & $\begin{array}{c}\text { Rabies virus, } \\
\text { Genus-Lyssavirus } \\
\text { Family-Rhabdoviridae }\end{array}$ & $\begin{array}{c}\text { Cattle, horses, cats, dogs, } \\
\text { bats, monkeys, wolves, } \\
\text { skunks, rabbits, and } \\
\text { coyotes }\end{array}$ & Nervous system \\
\hline Newcastle disease & $\begin{array}{c}\text { Paramyxovirus, } \\
\text { Genus-Avulavirus } \\
\text { Family-Paramyxoviridae }\end{array}$ & Poultry and wild birds & Conjunctivitis \\
\hline Avian influenza & $\begin{array}{l}\quad \text { Influenza A virus } \\
\text { Genus-Alphainfluenzavirus } \\
\text { Family-Orthomyxoviridae }\end{array}$ & $\begin{array}{c}\text { Ducks, chickens, turkeys, } \\
\text { dogs, cats, pigs, whales, } \\
\text { horses, seals, and wild } \\
\text { birds }\end{array}$ & $\begin{array}{l}\text { Flu like symptoms, diarrhea, } \\
\text { and pneumonia }\end{array}$ \\
\hline
\end{tabular}


Table 1. Cont.

\begin{tabular}{|c|c|c|c|}
\hline Disease & Etiology & Animal Host & $\begin{array}{c}\text { Major Symptoms, System or } \\
\text { Organs Involved }\end{array}$ \\
\hline Rift Valley fever & $\begin{array}{l}\text { Rift Valley fever virus } \\
\text { Genus-Phlebovirus } \\
\text { Family-Bunyaviridae }\end{array}$ & $\begin{array}{l}\text { Buffaloes, camels, cattle, } \\
\text { goats, and sheep }\end{array}$ & $\begin{array}{l}\text { Influenza- like fever, muscle } \\
\text { pain, joint pain, and headache }\end{array}$ \\
\hline $\begin{array}{l}\text { Ebola virus disease } \\
\text { (Ebola Hemorrhagic } \\
\text { Fever) }\end{array}$ & $\begin{array}{l}\text { Ebola virus } \\
\text { Genus_Ebolavirus } \\
\text { Family_Flaviviridae }\end{array}$ & $\begin{array}{l}\text { Monkeys, gorillas, } \\
\text { chimpanzees, apes, and } \\
\text { wild antelopes }\end{array}$ & $\begin{array}{l}\text { Fever, intense weakness, } \\
\text { muscle pain, headache, sore } \\
\text { throat, hemorrhage, vomiting, } \\
\text { diarrhea, kidney, and liver } \\
\text { failure }\end{array}$ \\
\hline $\begin{array}{l}\text { Marburg viral } \\
\text { hemorrhagic fever }\end{array}$ & $\begin{array}{l}\text { Marburg virus } \\
\text { Genus-Marburgvirus } \\
\text { Family_Flaviviridae }\end{array}$ & Fruit bats and monkeys & $\begin{array}{c}\text { Hemorrhage, fever, muscle } \\
\text { pains, watery diarrhea, } \\
\text { abdominal pain, and non-itchy } \\
\text { rash }\end{array}$ \\
\hline Chikungunya fever & $\begin{array}{l}\text { Chikungunya virus } \\
\text { Genus-Alphavirus } \\
\text { Family-Togaviridae }\end{array}$ & $\begin{array}{l}\text { Monkeys, birds, and } \\
\text { rodents }\end{array}$ & $\begin{array}{l}\text { High fever, severe joint pain, } \\
\text { muscle pain, and skin rash }\end{array}$ \\
\hline Dengue fever & $\begin{array}{c}\text { Dengue virus } \\
\text { Genus_Flavivirus } \\
\text { Family_Flaviviridae }\end{array}$ & Monkeys and dogs & $\begin{array}{l}\text { High fever, skin rash, skin } \\
\text { hemorrhage, and shock }\end{array}$ \\
\hline $\begin{array}{c}\text { Hantavirus infection } \\
\text { (Hantavirus Pulmonary } \\
\text { Syndrome) }\end{array}$ & $\begin{array}{c}\text { Hantavirus } \\
\text { Genus-Orthohantavirus } \\
\text { Family-Hantaviridae }\end{array}$ & $\begin{array}{l}\text { Deer mice, cotton rats, } \\
\text { rice rats, white-footed } \\
\text { mice, shrews, and moles }\end{array}$ & $\begin{array}{l}\text { Respiratory problem, high } \\
\text { fever, dizziness, chills, and } \\
\text { abdominal problems }\end{array}$ \\
\hline Zika fever & $\begin{array}{c}\text { Zika virus } \\
\text { Genus_Flavivirus } \\
\text { Family_Flaviviridae }\end{array}$ & Apes and monkeys & Fever, pain, and conjunctivitis \\
\hline West Nile fever & $\begin{array}{l}\text { West Nile virus } \\
\text { Genus_Flavivirus } \\
\text { Family_Flaviviridae }\end{array}$ & $\begin{array}{l}\text { Horses, birds, and } \\
\text { reptiles }\end{array}$ & $\begin{array}{l}\text { Headache, skin rash, swollen } \\
\text { lymph nodes, stiff neck, } \\
\text { disorientation, coma, tremors, } \\
\text { convulsions, and paralysis }\end{array}$ \\
\hline AIDS & $\begin{array}{l}\text { HIV } \\
\text { Genus-Lentivirus } \\
\text { Family-Retroviridae }\end{array}$ & $\begin{array}{l}\text { Monkeys and } \\
\text { chimpanzees }\end{array}$ & $\begin{array}{c}\text { Immunosuppression, } \\
\text { influenza-like symptoms, } \\
\text { fever, chills, rash, night sweats, } \\
\text { muscle aches, fatigue, swollen } \\
\text { lymph nodes }\end{array}$ \\
\hline $\begin{array}{l}\text { Severe acute respiratory } \\
\text { syndrome (SARS) }\end{array}$ & $\begin{array}{c}\text { SARS coronavirus } \\
\text { (SARS-CoV) } \\
\text { Genus-Coronavirus } \\
\text { Family-Coronaviridae }\end{array}$ & $\begin{array}{l}\text { Bats, dogs, cats, ferrets, } \\
\text { minks, tigers, and lions }\end{array}$ & $\begin{array}{l}\text { influenza-like symptoms, } \\
\text { fever, muscle pain, severe } \\
\text { cases progress to a respiratory } \\
\text { disease and pneumonia }\end{array}$ \\
\hline Monkey pox & $\begin{array}{l}\text { Monkeypox virus } \\
\text { Genus-Orthopoxvirus } \\
\text { Family-Poxviridae }\end{array}$ & $\begin{array}{l}\text { Squirrels, Gambian } \\
\text { poached rats, dormice, } \\
\text { different species of } \\
\text { monkeys, and others. }\end{array}$ & Fever, pox lesions on skin \\
\hline \multicolumn{4}{|c|}{ Parasitic zoonoses } \\
\hline Trichinellosis & Trichinella spp. & $\begin{array}{l}\text { Pigs, dogs, cats, rats, and } \\
\text { other wild species }\end{array}$ & $\begin{array}{l}\text { Gastrointestinal, e.g., nausea, } \\
\text { vomiting, diarrhea, and } \\
\text { abdominal pain }\end{array}$ \\
\hline Visceral larva migrans & $\begin{array}{c}\text { Baylisascaris procyonis, } \\
\text { Toxocara canis, } \\
\text { Toxocara cati, and } \\
\text { Ascaris suum }\end{array}$ & $\begin{array}{l}\text { Birds, emus, cats, } \\
\text { chinchillas, porcupines, } \\
\text { prairie dogs, rabbits, } \\
\text { weasels, woodchucks, } \\
\text { and woodrats }\end{array}$ & $\begin{array}{l}\text { Gastrointestinal, e.g., } \\
\text { coughing, shortness of breath, } \\
\text { fever, and abdominal pain }\end{array}$ \\
\hline $\begin{array}{l}\text { Cutaneous larval } \\
\text { migrans }\end{array}$ & Ancylostoma braziliense & Dogs and cats & Subcutaneous tissue \\
\hline
\end{tabular}


Table 1. Cont.

\begin{tabular}{|c|c|c|c|}
\hline Disease & Etiology & Animal Host & $\begin{array}{c}\text { Major Symptoms, System or } \\
\text { Organs Involved }\end{array}$ \\
\hline Hydatidosis & Echinococcus granulosus & $\begin{array}{l}\text { Buffaloes, sheep, goats } \\
\text { and adult stray or } \\
\text { shepherd dogs }\end{array}$ & $\begin{array}{l}\text { Hydatid cysts in liver, lungs, } \\
\text { bones, kidneys, spleen, } \\
\text { abdominal pain, and } \\
\text { respiratory problem }\end{array}$ \\
\hline Cryptococcosis & Cryptococcus neoformans & $\begin{array}{c}\text { Dogs, cattle, horses, } \\
\text { sheep, goats, birds, and } \\
\text { wild animals }\end{array}$ & $\begin{array}{l}\text { Respiratory problems, fever, } \\
\text { nausea, and vomiting }\end{array}$ \\
\hline Cryptosporidiosis & Cryptosporidium parvum & $\begin{array}{l}\text { Cattle, sheep, pigs, goats, } \\
\text { horses, and deer }\end{array}$ & $\begin{array}{l}\text { Diarrhea lasting 3-14 days. } \\
\text { Abdominal pain, nausea and } \\
\text { malaise are frequent. Some } \\
\text { patients have a slight fever }\end{array}$ \\
\hline Fascioliasis & $\begin{array}{l}\text { Fasciola hepatica, } \\
\text { Fasciola gigantica }\end{array}$ & $\begin{array}{l}\text { Cattle, sheep, goats, and } \\
\text { other ruminants }\end{array}$ & $\begin{array}{l}\text { Intense internal bleeding, } \\
\text { fever, nausea, swollen liver, } \\
\text { skin rashes, and extreme } \\
\text { abdominal pain }\end{array}$ \\
\hline \multicolumn{4}{|c|}{ Mycotic/Fungal zoonoses } \\
\hline $\begin{array}{l}\text { Tinea/ringworm } \\
\text { infection }\end{array}$ & $\begin{array}{l}\text { Microsporum spp., } \\
\text { Trichophyton spp. }\end{array}$ & $\begin{array}{l}\text { All animals like cattle, } \\
\text { sheep, goats, cats, and } \\
\text { dogs }\end{array}$ & Skin lesions \\
\hline Aspergillosis & Aspergillus spp. & $\begin{array}{l}\text { All domestic animals } \\
\text { and birds }\end{array}$ & Respiratory problems \\
\hline Blastomycosis & Blastomyces dermatitidis & $\begin{array}{l}\text { Mostly dogs, cats, and } \\
\text { less common in horses, } \\
\text { ferrets, deer, wolves, } \\
\text { African lions, } \\
\text { bottle-nosed dolphins, } \\
\text { and sea lions }\end{array}$ & $\begin{array}{l}\text { Fever, malaise, pneumonia, } \\
\text { verrucous skin lesions, } \\
\text { subacute meningitis, gait } \\
\text { abnormalities, and seizures }\end{array}$ \\
\hline Coccidioidomycosis & $\begin{array}{l}\text { Coccidioides immitis, } \\
\text { Coccidioides posadasii }\end{array}$ & $\begin{array}{l}\text { Dogs, horses, pigs, and } \\
\text { ruminants }\end{array}$ & $\begin{array}{l}\text { Hypersensitivity reaction, } \\
\text { fever, erythema nodosum, } \\
\text { erythema multiform, } \\
\text { arthralgia, pleuritic chest pain, } \\
\text { and dry cough }\end{array}$ \\
\hline Cryptococcosis & Cryptococcus neoformis & $\begin{array}{l}\text { Cats, dogs, cattle, horses, } \\
\text { sheep, goats, birds, and } \\
\text { wild animals }\end{array}$ & $\begin{array}{c}\text { Meningitis, fever, malaise, } \\
\text { headache, neck stiffness, } \\
\text { photophobia, cough, nausea, } \\
\text { and vomiting }\end{array}$ \\
\hline Sporotrichosis & Sporothrix schenckii & $\begin{array}{l}\text { Dogs, cats, horses, cows, } \\
\text { camels, dolphins, goats, } \\
\text { mules, birds, pigs, rats, } \\
\text { and armadillos }\end{array}$ & $\begin{array}{l}\text { Erythematous papulonodular } \\
\text { lesions, cough, low-grade } \\
\text { fever, weight loss, pulmonary } \\
\text { dysfunction, and lung abscess }\end{array}$ \\
\hline Malassezia infection & Malassezia spp. & Dogs and cats & $\begin{array}{c}\text { Pityriasis versicolor, seborrheic } \\
\text { dermatitis, atopic eczema, } \\
\text { folliculitis, and dandruff }\end{array}$ \\
\hline Histoplasmosis & $\begin{array}{l}\text { Histoplasma capsulatum } \\
\text { var. capsulatum }\end{array}$ & $\begin{array}{c}\text { Cats, dogs, rabbits, and } \\
\text { rats }\end{array}$ & $\begin{array}{l}\text { Often asymptomatic, fever, } \\
\text { productive cough, chest pain, } \\
\text { weight loss, } \\
\text { hepatosplenomegaly, and } \\
\text { hematologic disturbances }\end{array}$ \\
\hline
\end{tabular}


Table 1. Cont.

\begin{tabular}{|c|c|c|c|}
\hline Disease & Etiology & Animal Host & $\begin{array}{c}\text { Major Symptoms, System or } \\
\text { Organs Involved }\end{array}$ \\
\hline \multicolumn{4}{|c|}{ Rickettsial zoonoses } \\
\hline Q-Fever & Coxiella burnetti & $\begin{array}{c}\text { Cattle, sheep, goats, } \\
\text { dogs, cats, chickens, and } \\
\text { wild animals }\end{array}$ & Fever, and skin rash \\
\hline Epidemic typhus & Rickettsia prowazekii & $\begin{array}{l}\text { Dogs, lambs, goat kids, } \\
\text { calves, donkeys, and } \\
\text { young camels }\end{array}$ & $\begin{array}{c}\text { High fever, headache, malaise, } \\
\text { myalgia, arthralgias, rashes, } \\
\text { CNS manifestations, petechiae, } \\
\text { and cough }\end{array}$ \\
\hline $\begin{array}{l}\text { Rocky mountain spotted } \\
\text { fever }\end{array}$ & Rickettsia rickettsii & Rodents and dogs & $\begin{array}{l}\text { Fever, headache, rash, malaise, } \\
\text { myalgia, anorexia, nausea, } \\
\text { vomiting, abdominal pain, and } \\
\text { photophobia }\end{array}$ \\
\hline Queensland tick typhus & Rickettsia australis & $\begin{array}{l}\text { Bandicoots, rodents, } \\
\text { cattle, wombats, and } \\
\text { companion animals }\end{array}$ & $\begin{array}{l}\text { Mild fever, macular, papular, } \\
\text { or maculo-papular rash, rigors, } \\
\text { myalgia, arthralgia, acute } \\
\text { renal failure, headache, and } \\
\text { lymphadenopathy }\end{array}$ \\
\hline Scrub typhus & Orientia tsutsugamushi & Rodents & $\begin{array}{l}\text { Fever, rash, myalgia, diffuses } \\
\text { lymphadenopathy, necrotic } \\
\text { eschar, cough, and headache, } \\
\text { diarrhea }\end{array}$ \\
\hline \multicolumn{4}{|c|}{ Chlamydial zoonoses } \\
\hline Enzootic abortion & Chlamydia abortus & $\begin{array}{l}\text { Cattle, horses, sheep, } \\
\text { pigs, cats, and rabbits }\end{array}$ & Abortion \\
\hline Psittacosis & Chlamydia psittaci & $\begin{array}{l}\text { Parrots, parakeets, lories, } \\
\text { cockatoos, cattle, sheep, } \\
\text { and goats }\end{array}$ & $\begin{array}{l}\text { Cough, dyspnea, pleuritic } \\
\text { chest pain, epistaxis, sore } \\
\text { throat, hemoptysis, fever, } \\
\text { malaise, anorexia, chills, } \\
\text { nausea, vomiting, myalgias, } \\
\text { arthralgias, headache, and } \\
\text { abdominal pain }\end{array}$ \\
\hline Chlamydiosis & $\begin{array}{c}\text { Chlamydia felis, } \\
\text { Chlamydia trachomatis }\end{array}$ & Cats and mice & $\begin{array}{l}\text { Conjunctivitis, urethritis, } \\
\text { cervicitis, pelvic inflammatory } \\
\text { disease, ectopic pregnancy, } \\
\text { tubal factor infertility, } \\
\text { epididymitis, proctitis, and } \\
\text { reactive arthritis (sequelae) }\end{array}$ \\
\hline \multicolumn{4}{|c|}{ Protozoal zoonoses } \\
\hline Trypanosomiasis & Trypanosoma brucei & $\begin{array}{l}\text { Antelopes, cattle, camels, } \\
\text { and horses }\end{array}$ & $\begin{array}{c}\text { chronic and intermittent fever, } \\
\text { headache, pruritus, } \\
\text { lymphadenopathy, } \\
\text { hepatosplenomegaly, and } \\
\text { sleep disturbance }\end{array}$ \\
\hline Leishmaniasis & Leishmania infantum & $\begin{array}{l}\text { Cats, dogs, horses, and } \\
\text { bats }\end{array}$ & $\begin{array}{c}\text { Skin lesions, } \\
\text { hepatosplenomegaly, and } \\
\text { wasting }\end{array}$ \\
\hline African sleeping sickness & Trypanosoma brucei & $\begin{array}{l}\text { Antelopes, cattle, camels, } \\
\text { and horses }\end{array}$ & $\begin{array}{l}\text { High fever, headache, nausea, } \\
\text { vomiting, and erythematous } \\
\text { plaque formation }\end{array}$ \\
\hline
\end{tabular}


Table 1. Cont.

\begin{tabular}{|c|c|c|c|}
\hline Disease & Etiology & Animal Host & $\begin{array}{c}\text { Major Symptoms, System or } \\
\text { Organs Involved }\end{array}$ \\
\hline Chagas disease & Trypanosoma cruzi & $\begin{array}{l}\text { Domestic pigs and cats, } \\
\text { wildlife reservoirs } \\
\text { include opossums, } \\
\text { armadillos, raccoons, } \\
\text { and woodrats }\end{array}$ & $\begin{array}{l}\text { severe myocarditis, } \\
\text { meningoencephalitis, swelling } \\
\text { or redness of skin, fever, } \\
\text { swollen lymph nodes, head or } \\
\text { body aches, fatigue, nausea, } \\
\text { vomiting, and diarrhea }\end{array}$ \\
\hline Giardiasis & Giardia lamblia & $\begin{array}{l}\text { Dogs, cats, ruminants, } \\
\text { and pigs }\end{array}$ & $\begin{array}{l}\text { Diarrhea, abdominal } \\
\text { cramping, bloating, flatulence, } \\
\text { malaise, nausea, and anorexia }\end{array}$ \\
\hline Toxocariasis & $\begin{array}{l}\text { Toxocara canis, } \\
\text { Toxocara cati }\end{array}$ & Dogs and cats & $\begin{array}{c}\text { Fever, anorexia, } \\
\text { hepatosplenomegaly, rash, } \\
\text { pneumonitis, asthma, and } \\
\text { visual impairment }\end{array}$ \\
\hline Toxoplasmosis & Toxoplasma gondii & $\begin{array}{l}\text { Pigs, sheep, goats, } \\
\text { poultry, and rabbits }\end{array}$ & $\begin{array}{l}\text { Lymphadenopathy, fever, } \\
\text { malaise, night sweats, myalgia, } \\
\text { sore throat, and } \\
\text { maculopapular rash }\end{array}$ \\
\hline Balantidiasis & Balantidium coli & $\begin{array}{c}\text { Ruminants, pigs, guinea } \\
\text { pigs and rats }\end{array}$ & $\begin{array}{l}\text { Chronic diarrhea, occasional } \\
\text { dysentery, nausea, foul breath, } \\
\text { colitis, abdominal pain, weight } \\
\text { loss, and deep intestinal } \\
\text { ulcerations }\end{array}$ \\
\hline \multicolumn{4}{|c|}{ Disease caused by acellular non-viral pathogenic agents } \\
\hline $\begin{array}{l}\text { Mad Cow Disease, also } \\
\text { known as BSE (Bovine } \\
\text { spongiform } \\
\text { encephalopathy). In } \\
\text { human known as } \\
\text { Creutzfeldt-Jakob } \\
\text { disease (CJD) }\end{array}$ & Prion protein & $\begin{array}{l}\text { Cattle, sheep, goats, } \\
\text { mink, deer, and elks }\end{array}$ & $\begin{array}{l}\text { Ataxia, jerky movements, } \\
\text { seizures, dementia, memory } \\
\text { loss, and personality changes }\end{array}$ \\
\hline
\end{tabular}

The older classification of zoonoses includes the terms anthropozoonoses, zooanthroponoses, amphixenoses, and euzoonoses [8]. Anthropozoonoses are animal diseases that can be transmitted to humans, such as rabies. Zooanthroponoses refers to those diseases that are transmitted to animals from humans such as tuberculosis in cat and monkey. Amphizoonoses are those diseases that can be transmitted in any direction (from human to animal and from animal to human) such as staphylococcal infection. For some parasitic diseases, humans act as the obligatory host. These parasitic diseases are known as Euzoonoses such as Taenia solium and Taenia saginata infections.

Both Gram-negative and Gram-positive bacteria are capable of inducing zoonoses. Based on etiology, bacteria account for most zoonotic diseases. It has been estimated that among the zoonotic pathogens originating from bovine origins, about $42 \%$ are of bacterial origin, $22 \%$ viral, $29 \%$ parasitic, $5 \%$ fungal, and $2 \%$ prion origin [9]. Similarly, both DNA and RNA viruses are known to be responsible for zoonoses; however, compared to DNA, the RNA viruses are more frequently linked with zoonoses [10].

Pathogens can be transmitted to humans directly or indirectly from animals. Diseases that are transmitted directly to humans from animals through media such as air are known as direct zoonoses [11]. One classical example of direct zoonoses is avian influenza, which is a viral disease that spreads from animals to humans through droplets or fomites. Infected animals can also directly transfer pathogens to susceptible humans by bites such as in the case of rabies, which is one of the deadliest zoonotic diseases. It is caused by a rabies virus that belongs to Rhabdoviridae. When a rabid animal (dog, bat, monkey, skunk, raccoon, or fox) bites a human, the virus directly enters the human body through saliva. Similarly, pathogens can be transmitted to human via vectors (Dengue fever). 
Arthropods like mosquitoes and ticks are often considered to be the only vectors; however, any animal that has the potential to transmit pathogens to human can be considered a vector [12].

Depending on the ecosystem in which pathogens circulate, zoonotic diseases are classified into several categories. For example, some zoonoses are classified into synanthropic zoonoses and exoanthropic zoonoses. Synanthropic zoonoses have an urban (domestic) cycle in domestic and synanthropic animals such as with urban rabies and zoonotic ringworm. Exoanthropic zoonoses are usually accompanied by a sylvatic (feral and wild) cycle in natural foci outside human habitats such as with arboviroses, wildlife rabies, and Lyme disease [13]. However, some zoonoses can also circulate in both urban and natural cycles such as yellow fever, Chagas disease, and dengue fever. In addition, there are some other zoonotic diseases that can be transmitted by arthropods, food, rodents, and some are waterborne [14].

Many zoonotic pathogens are able to replicate in and survive on dead organic materials like saprophytes and the diseases caused by these agents are known as sapronoses. Examples of sapronoses include fungal diseases (such as coccidioidomycosis, histoplasmosis, and aspergillosis) and bacterial diseases (such as legionellosis) [15]. The term "saprozoonoses," is defined by the WHO expert committee on zoonoses as pathogens that have a vertebrate host as well as a non-animal reservoir or developmental site (soil, plants, and organic matter) [16]. In many cases, disease transmission may require more than one vertebrate host such as with human taeniasis. These types of zoonoses are known as cyclozoooses. Zoonoses in which both vertebrate and invertebrate hosts are involved are known as metazoonoses such as with arbovirus infection.

Most zoonotic diseases are transmitted to humans from animals. Some reports suggested that animals can also get infected from humans [17-20]. Such diseases are known as reverse zoonoses. Examples of such pathogens include methicillin-resistant Staphylococcus aureus (MRSA), Campylobacter spp., Salmonella enterica Serovar Typhimurium, influenza A virus, Cryptosporidium parvum, Ascaris lumbricoides, and Giardia duodenalis. In addition, zoonotic diseases caused by pathogens that are occasionally transmitted to animals from humans and then back from animals to humans are referred to as reverse zoonoses (Table 2).

Table 2. Examples of reverse zoonoses (retrieved from [21]).

\begin{tabular}{cccc}
\hline Agent & Human Disease & Animal Disease & Animal Affected \\
\hline Mumps virus & Mumps & Parotiditis & Dogs \\
\hline $\begin{array}{c}\text { Infectious hepatitis } \\
\text { Corynebacterium } \\
\text { diphtheriae }\end{array}$ & Hepatitis & Hepatitis & Nonhuman primates \\
\hline Staphylococcus aureus & Diphtheria & Ulcers on teats, mastitis & Cattle \\
\hline Streptococcus pyogenes & Pharyngitis, scarlet fever & Furunculosis, mastitis & Cattle \\
\hline Giardia lamblia & $\begin{array}{c}\text { Nausea, flatulence } \\
\text { diarrhea }\end{array}$ & None known & Cattle \\
\hline $\begin{array}{c}\text { Mycobacterium } \\
\text { tuberculosis }\end{array}$ & Tuberculosis & Tuberculosis & Deavers \\
\hline
\end{tabular}

\section{Zoonoses of Domestic Animals}

Domestic animals play a significant role in the transmission of various diseases to humans and in many cases, they work as amplifiers of pathogens emerging from wild animals [22]. The positive association between domestic animals and humans in influencing pathogen diversity was first hypothesized long time ago [23]. About 60\% human infectious diseases come from vertebrate animals $[5,24]$. Direct human contact with animals has expanded with the introduction of domestication of different vertebrate animals [25]. The possible transmission patterns of zoonotic bacteria, virus, parasites, or fungi are via direct contact, ingestion, inhalation, through conjunctiva, or biting [24]. 
Cattle, sheep, goats, dogs, cats, horses, pigs, and other domestic animals act as reservoirs of pathogens of domestic zoonoses and can transmit the diseases to humans [26]. Pathogens can be transmitted through direct contact or animal origin foods. Examples of zoonotic diseases that can be transmitted to humans from domestic animals include anthrax, rabies, tuberculosis, brucellosis, campylobacteriosis, leptospirosis, toxoplasmosis, balantidiasis, ancylostomiasis, toxocariasis, listeriosis, bovine pustular stomatitis, rotavirus infection, and $Q$ fever $[10,26,27]$.

Of these zoonotic diseases transmitted by domestic animals, anthrax caused by Bacillus anthracis poses a significant public health importance. B. anthracis is soil-borne bacteria with the capability to produce spores; thus, allowing them to survive in the environment for a very long time. Anthrax can be transmitted to humans through close contact with infected animals (such as cattle and goat) or their products (such as meat, skin, hides, or even bones). [28]. Human to human transmission exists, but it is very rare. Every year, about 2,000-20,000 humans are affected by anthrax cases globally [28]. People from India, Bangladesh, Pakistan, United States, Zimbabwe, Iran, Iraq, South Africa, Turkey are occasionally affected [28]. In humans, it can develop malignant pustule, gastroenteritis, pneumonitis; conversely sudden death with some systemic lesions can occur in animals. Mortality can be $25-65 \%$ in intestinal anthrax; however, it may rise up to $100 \%$ in pulmonary anthrax [29]. Developing countries whose economy usually depends on agriculture are still facing hazardous effects due to anthrax.

Among the bovine zoonoses having serious public health significance, tuberculosis is the most important zoonotic disease. The disease has been significantly a cause for severe economic loss in animal production. It is caused by Mycobacterium bovis, M. tuberculosis, or rarely M. caprae [30-32]. Mycobacterium are acid-fast soil saprophytes characterized by the presence of mycolic acid in their cell wall. They are also facultative intracellular pathogens. Though bovine tuberculosis has been greatly eliminated from developed countries, other parts of the globe are still facing serious zoonotic effects. Human tuberculosis is the second most common cause of death after AIDS. About $5-10 \%$ of all human tuberculosis has been caused by M. bovis ( $25 \%$ of the patients were children). About $53 \%$ of all cases showed that the favorable site of tuberculosis is the extra-pulmonary tract [26]. Most humans are affected with tuberculosis by handling or milking unpasteurized contaminated milk or via aerosols from coughing of infected animals [33]. Importantly, M. bovis infection can also happen in the urogenital system of humans and can impact animals through the respiratory secretions from humans acting as reverse zoonoses [34]. However, direct contact of infected animals with humans such as farm workers, veterinarians, abattoir workers, or village people can pose a significant risk.

Brucellosis is one of the most common bacterial zoonotic diseases causing over 500,000 human cases throughout the world every year [35]. The disease is classified as a forgotten neglected zoonosis as per the WHO [36]. Among the twelve species of the genus Brucella, Brucella melitensis, B. abortus, B. suis, and B. canis are zoonotic in nature. The common transmission pattern of brucellosis to human occurs through the consumption of unpasteurized milk or milk products, though the human-human transmission is rare. Transmission through the inhalation of aerosols and contact with secretions has also been reported [37]. In humans, brucellosis mainly causes influenza-like infections, pneumonia, and other complications including meningitis, endocarditis, septicemia, serious weakness, pain in muscle and joints, extreme headache, fever, and night sweats. In animals, brucellosis causes abortion, lameness, abscess, reduction in milk production, and decrease in survival chances of newborns [10,38]. Dairy farm workers, caretakers, abattoir workers, veterinarians, and village people are at high risk for brucellosis infection.

Rabies is one of the deadliest zoonotic disease caused by rabies virus, which belongs to Rhabdoviridae. Every year about 30,000-70,000 human deaths occur throughout the globe [39]. Though dogs are the main carriers of rabies virus, other wild animals including cats and jackals also act as carriers for the transmission of rabies virus. In developing countries, humans are affected by rabies through biting because of the stray dog problem [40]. In developed countries, bats, foxes, and other wild animals are responsible for the transmission of rabies [40]. Severity and gravity of wound, its anatomical location, and viral load can influence the incubation period of rabies, which may vary from four days 
to several years [41-43]. Furious or classical or encephalitic form and paralytic or dumb form are the diversified clinical characteristics of rabies, though they are usually dominated by viral tropisms and neural sites and spread, volatile immune response or other potential mechanisms [43-48]. The most common symptoms of the disease include excitation, solicitude, anxiety, bewilderment, hallucination, and hydrophobia [27].

\section{Zoonoses of Pets, Companion Animals, and Birds}

About $14-62 \%$ of pet owners allow their pets to their bedrooms, which could enhance the emergence of zoonoses [49]. Companion and pet animals have increased over the past several decades, but they are also a comprehensive source of disease-producing agents. The increased popularity of pets and companion animals has put human health at risk due to the possible spread of infections. In many houses nowadays, pets of exotic species are kept along with common pets. Therefore, huge people are at risk of acquiring new zoonotic disease from pets, companion animals, and exotic birds and animals.

A variety of infectious diseases (viral, bacterial, parasitic, and fungal) are associated with pets and companion animals [50]. The zoonotic diseases frequently associated with pets and companion animal include brucellosis, campylobacteriosis, chlamydiosis, catch scratch fever (Bartonella henselae), ehrlichiosis, giardiasis, hantavirus, hookworms, influenza, rabies, Lyme disease, rocky mountain spotted fever, leptospirosis, monkey pox, pasteurellosis, $\mathrm{Q}$ fever, plague, roundworms, salmonellosis, staphylococcosis (MRSA), streptococcosis, toxoplasmosis, and tularemia [50-52]. Many types of zoonoses such as salmonellosis, staphylococcosis, and rabies are found in a wide range of pets and companion animals.

Nowadays, birds like canaries, finches, sparrows, parrots, parakeets, budgerigars are very common in the developed and developing countries [53]. Like pet animals, these game and ornamental birds are also potential transmitters of zoonotic diseases like Coxiella burnetii, Coxiella psittaci, Salmonella spp., Listeria monocytogenes, Erysipelothrix rhusiopathiae, Mycobacterium spp., Lyme disease, and transmitters of different viruses like fowl pox virus and Newcastle disease virus [54]. Many of these pathogens are potentially enough to cause serious diseases in human such as salmonellosis, chlamydiosis, and avian influenza A H5N1 [53]. In addition, there are wide varieties of other bacterial zoonoses in game and ornamental birds including Pasteurella spp., Klebsiella spp., Yersinia spp., Pseudomonas spp., Staphylococcus aureus and E. coli [55-57]. In fact, there is evidence of Escherichia coli O157:H7 (enterohaemorrhagic) transmission to human through food of animals that originally came from wild passerines (such as European starlings) [58].

Transmission of pathogens from these animals occurs through direct or indirect contact. The transmission can take place at home, outside, pet shops, hospitals, or other places. In many cases transmission also takes place when these animals and birds are brought to shows and competitions $[59,60]$. Usually, animal bites or scratches are routes through which humans get the infection such as pasteurellosis and cat scratch disease [61].

It is noteworthy that the most common dog-associated zoonotic disease is rabies is caused by rabies virus that kills tens of thousands of people every year [62]. Similarly, pet-associated MRSA is a serious health problem for human across the globe [63].

One of the important zoonoses associated with pet is cat-scratch disease. The etiological agent of the disease is Bartonella henselae. Cat-scratch disease is a common infectious disease and is usually benign. Cat-to-cat transmission of the disease takes place horizontally, but humans occasionally gets the infection by arthropod vectors like fleas and ticks. In addition, the most frequent transmission patterns in human include cat licking of open wounds of a person, or bites and scratches causing wounds. The incubation period of the disease varies from 3 to 14 days. Several lesions like swelling and redness with raised, round areas may appear, and pus may also form at the site of infection. Moreover, the lymph nodes near the bitten or scratched area or on the neck region are usually swollen [64]. Rearing pets with good hygiene practices as well as routine vaccination and medical checkup is needed to ensure their freedom from these kinds of zoonotic infections. 


\section{Zoonoses of Fish and Aquatic Environments}

Many microorganisms with zoonotic significance have been isolated from fish [65]. Fish-associated zoonotic pathogens are mainly bacteria. Often, fish unsusceptible to these infections are capable to cause serious sickness in humans. However, these opportunistic fish-borne bacterial infections are limited. Fish can get these pathogens from the aquatic environment where they remain as an indigenous part. In addition, aquatic environments may get contamination from agricultural activities, human and animal excreta, garbage from households, and wild animals. These zoonotic infections may be transmitted to humans through the non-hygienic handling of aquatic animals and/or their products. Consumption of raw or improperly cooked aquatic products may also transmit foodborne infections to humans. Among the zoonotic pathogens isolated from fish, Aeromonas hydrophila, E. coli, Yersinia spp., Brucella spp., Shigella spp., Salmonella spp., Streptococcus iniae, Clostridium botulinum, Klebsiella spp., and Edwardsiella tarda are important [66,67].

Several Vibrio species, at least 12, are often known to be potential for fish-associated zoonoses [68]. Among them Vibrio cholerae, V. parahaemolyticus, V. vulnificus, V. damsela are mostly involved in human illness $[69,70]$. Eating contaminated raw or undercooked seafood is the major way through which humans get these Vibrio infections, which can cause serious symptoms such as diarrhea, vomiting, and dehydration [71]. These fish-associated pathogens may be transmitted to humans through accidental ingestion of contaminated fish products (mostly contaminated with fish fecal materials) or directly though broken, wounded skin. In most of the cases, these fish pathogens are endogenous in origin. Cross-contamination with zoonotic pathogens like Listeria monocytogenes in ready-to-eat fish products has recently been reported [72].

In humans, Mycobacterium tuberculosis cause TB. However, fish are susceptible to non-tuberculous mycobacterial infections. The infections are commonly associated with display aquaria and occasionally with commercial aquaculture systems. They can also be transmitted to humans during aquaculture practice in farm and handling of ornamental fish in aquarium and equipment [73]. M. chelonae, M. marinum, and M. fortuitum are main concerns in aquaculture and fish-related businesses. Among these, M. marinum is a well-known zoonotic pathogen. In fish, M. marinum infection is chronic in nature and is characterized by granuloma formation involving different organs and tissues, discoloration and loss of scales, loss of appetite, and apathy [74]. Similarly, in humans too, it causes granulomatous inflammation and nodule formation in skin, subcutaneous tissues, and tendons $[75,76]$ and they are referred to as "fish tank granuloma", "swimming pool granuloma", "fish TB", "fish handlers", or "fish fancier's disease" [77].

Erysipelothrix rhusiopathiae is a fish-borne pathogen that causes systemic skin diseases in marine mammals [78]. It is a Gram-positive pathogen but there is no reported disease in fish that is caused by this bacterium [79]. Similar to other fish-borne pathogens, human and non-human animals are exposed to this bacterium through direct contact with cutaneous wounds on fish [65]. E. rhusiopathiae can cause diseases in humans (known as "erysipeloid") and animals (known as "erysipelas") [80]. Fisheries workers are directly vulnerable to the transmission of E. rhusiopathiae during the handling and processing of live and dead fish, which is the reason that the disease is also referred as fish-handler's disease [81]. The disease is also referred to as "fish rose" due to its symptoms, which include purple or red discoloration of the skin [81,82]. Although E. rhusiopathiae commonly causes localized infections, such as painful self-limiting cellulitis and edema, and systemic infection is rare in human, it can still cause serious endocarditis $[81,83,84]$. Among animals, pigs are the most vulnerable to E. rhusiopathiae and develops a disease entitled as "diamond skin disease" [80]. However, as the bacterium can survive in frozen conditions [85], fish handlers must take precautions during handling and processing of both fresh and frozen fish (such as wearing gloves or protective sleeves) and during cleaning the fish tanks or housing areas.

Lactococcus garvieae is an important fish-borne pathogen affecting a wide range of wild fish species (both marine and fresh water fish), giant prawns from fresh water, and wild marine mammals [86]. This bacterium causes severe hyperacute hemorrhagic septicemia (known as lactococcosis) in 
cultured warm-water fish with high mortality rates and an ultimate ominous impact on aquaculture industry $[80,87,88]$. L. garvieae has been isolated from ruminants (with subclinical mastitis), cow's milk, beef meat, goat cheese; and poultry meat, and pork (from pigs with pneumonia) [86,89]. L. garvieae is an emerging zoonotic fish-borne pathogen that causes endocarditis, bacteremia, peritonitis and/or bacterioascites, espondilodiscitis, diskospondylitis, hip prosthetic infection, acalculous cholecystitis, and meningitis in human $[86,90,91]$. The transmission patterns of $L$. garvieae from fish to humans include direct contact with the contaminated raw fish during handling and processing and the consumption of contaminated raw fish and seafood [86].

Nocardia spp. affect fish such as teleost, shellfish, rainbow trout, blueback salmon, and pacific oyster causing nocardiosis, which is a lethal granulomatous disease developed in the skin, muscle, and inner tissues [92]. Examples include Nocardia asteroides, N. seriolae, N. salmonicida, and N. crassostreae, which are all associated with fish and aquatic environments. The primary route of transmission is via wounds [93]. Nocardia spp. have also been reported in humans, ruminants (cattle and goats), cats, and marine mammals [94,95]. Among different Nocardia spp., N. farcinica, N. brasiliensis, and N. otitidiscaviarum are closely associated with human infections whereas $N$. asteroides is occasionally associated with human infections [80]. Generally, immunosuppressed patients are more vulnerable to nocardiosis. The disease is characterized by skin infections, pneumonia, and ulcers [96]. It is important to mention that there is a scarcity of data on genetic or epidemiological linkages between piscine and human nocardiosis [80].

\section{Zoonoses Associated with Food-Borne Pathogens}

Food acts as an important medium to transmit pathogens-known as food-borne pathogens-which usually cause diarrheal diseases. Many food-borne illnesses are caused by zoonotic pathogens. Food-borne pathogens can cause significant morbidity and mortality in adult and pediatric populations. Mortality, which impacts millions, is often associated with diarrheal diseases caused by contaminated food and drinking water [97]. It is estimated that about 600 million ( 1 in 10 persons around the world) people annually consume contaminated food and water. Among these affected people, 420,000 people including 125,000 children die [98]. Risk factors influencing food-borne zoonoses include handling and slaughtering of animals without appropriate precautions, and consuming undercooked animal-based food.

Common food-borne zoonotic pathogens include Salmonella spp. (Salmonella enterica serovar Enteritidis), Campylobacter spp., Shiga toxin-producing Escherichia coli (STEC), and hepatitis E virus. More than $90 \%$ of bacteria-triggered food-borne illnesses are caused by Salmonella spp. and Campylobacter spp. [99]. All domestic livestock, including poultry, can act as a reservoir for bacteria causing food-borne illness [100-102].

STEC is also known as verodoxin (Verocytotoxin)-producing E. coli. They can be transmitted from contaminated foods to human by direct contact [103]. Escherichia coli O157:H7 serotype of STEC was recorded as a major cause of food-borne zoonotic illness in 1980s and 1990s. Toxins produced from STEC strains can cause serious illness in humans including gastrointestinal symptoms, kidney failure, and bloody diarrhea $[104,105]$. In serious cases, STEC can induce severe complications such as hemolytic uremic syndrome (HUS), which can have fatal consequences. STEC infections can cause severe illness with high mortality in both young and elderly populations [99].

In addition, Brucella spp., Listeria spp., Clostridium spp., BSE, norovirus, calicivirus, and other hepatitis viruses, mainly found in intestines of animals, can be transmitted through contaminated food materials. There are several risk factors influencing the occurrence of food-borne zoonotic diseases such as globalization of farm animals and their meat market, consuming uncooked or undercooked food from wildlife, an increasing number of immunocompromised patients, and lack of adequate awareness regarding proper hygiene and good sanitation. 


\section{Potential Zoonoses Transmitted by Edible Insects}

Edible insects are under-utilized food sources with a usually high nutritional content. They are becoming more popular due to the increased demand for digestible, palatable, and nourishing food products [106,107]. Insects consumed by human include beetles, caterpillars, ants, bees, wasps, grasshoppers, locusts, true bugs, dragonflies, termites, flies, cockroaches, and spiders. About two billion people use some of these insects as food sources throughout the world, especially in Asia, South America, and Africa [108].

Many of these edible insects pose health risks to humans through causing allergies and other disease conditions [109]. For example, edible insects such as caterpillars can provoke allergic reactions in children, which can include the symptoms of drooling, difficulty in breathing and swallowing, pain, and generalized urticaria. In addition, consuming mopane caterpillars and silkworm pupa has been shown to induce anaphylactic reactions in humans [110]. Moreover, edible insects, such as beetles can harbor metabolic steroids that may trigger hyper-fertility, retardation of growth, jaundice, edema, and liver cancer [111]. Lepidoptera and Coleoptera contain cyanogenic substances that can cause enzyme inhibition [111]. Longhorn beetles contain toluene; a nervous system depressant that can negatively impact brain and kidneys [111].

Edible insects can carry different infectious pathogens and parasites. Pathogens have been extracted from edible insects such as Campylobacter spp. from darkling beetles or buffalo worms (Alphitobius diaperinus); Enterobacteriaceae from Tenebrio molitor, Acheta domesticus, and Brachytrupes spp.; and Micrococcus spp., Lactobacillus spp., and Staphylococcus spp. from Zoophobas morio, Tenebrio molitor, Galleria mellonella, and Acheta domesticus [109,112]. In addition, edible insects can act as a critical vector for the zoonotic food-borne pathogens Salmonella spp. and E. coli [113-116]. Salmonella, detectable in beetles, are vastly distributed in and around livestock areas posing serious threat to animals [110].

Parasitic infections have also been reported from edible insect consumption. For example, Gongylonema pulchrum and Dicrocoelium dendriticum infections having zoonotic potential are transmitted to human via ingestion of ants [117]. Edible insects, such as beetles, cockroaches, and flies, could also harbor Isospora spp., Giardia lamblia, Balantidium spp., Toxoplasma spp., Entamoeba spp., Pharyngodon spp., Spirura infundibuliformis, and Sarcocystis spp. [107,118].

\section{Emerging and Re-Emerging Zoonoses}

Emerging zoonosis is a zoonosis that is newly recognized, newly evolved, or has occurred previously but shows an increase in incidence or expansion in geographical, host or vector range [119]. At least 250 zoonoses were listed as emerging and re-emerging zoonotic diseases during the last 70 years. These diseases have been spread rapidly throughout the world with increasing incidence along with geographical range [6]. Human are affected due to close contact with animals which act as reservoirs for emerging and re-emerging zoonotic diseases [120].

Increased human-animal contact or interaction resulting from changes in human and animal behavior, habitat, ecology, vector biology, pathogen adaptability, change in farm practices, livestock production systems, food safety, urbanization, deforestation, and climate change are among the triggering factors for emergence of zoonotic diseases [121]. Wildlife can act as a source or a reservoir for emerging and remerging zoonotic disease-pathogens [122].

Emerging and re-emerging diseases have significant impacts, not only on public health, but also on socio-economic issues around the globe [123-126]. Among 175 reported emerging diseases, 132 diseases are considered to be emerging zoonotic diseases [5]. Another report estimated that about $60.3 \%$ of the emerging diseases can be categorized under zoonoses. Among them, $71.8 \%$ originated from wildlife [127].

Examples of major emerging zoonoses include avian influenza, bovine spongiform encephalopathy (BSE), feline cowpox, rotavirus infection, norovirus infection, Ebola, hantavirus infection, West Nile fever, canine leptospirosis, MRSA infection, cat scratch disease, severe fever with thrombocytopenia syndrome (SFTS), Middle East respiratory syndrome (MERS), severe acute respiratory syndrome 
(SARS), and the most recent coronavirus disease 2019 (COVID-19) [61,122,128]. On the other hand, rabies, brucellosis, Japanese encephalitis, tuberculosis (M. bovis), and Schistosoma japonica infection are considered to be re-emerging zoonoses in many parts of the world.

SFTS, caused by a bunyavirus member of the family Bunyaviridae, is a life-threatening disease that is characterized by the sudden onset of fever, thrombocytopenia, and leukopenia [129]. The vector of this disease is a tick named Ixodid (Haemaphysalis longicornis). Symptoms of SFTS include mild or severe febrile illness. The signs and symptoms are almost similar to those of hemorrhagic fever [130]. In severe cases, multi-organ failure occurs leading to the death of $6-30 \%$ of the patients [131]. The disease was first reported in May 2007 in central and northeast China [132]. People working in the mountain are more susceptible to the disease. In addition, people more than 50 years old are considered to be high-risk with higher rates of morbidity and mortality [133].

The disease can be transmitted by direct contact with animals and/or through contact vectors [134]. In endemic areas, animals carry antibodies that are specific to severe fever with thrombocytopenia syndrome (SETS) virus antigens [134]. The disease is usually transmitted horizontally. A similar type of the bunyavirus-associated disease, with SFTS-like clinical signs, was later detected in USA, Japan, and South Korea. These observations have caused the disease to be regarded as an emerging zoonotic disease in different parts of the world [135-137].

Middle East Respiratory Syndrome (MERS), which is transmitted to humans from camels, is an emerging viral zoonotic disease. MERS first emerged in Saudi Arabia in 2012 [138]. The disease is caused by a coronavirus known as the MERS coronavirus (MERS-CoV). MERS infections can cause significant mortality rates and deleterious public health impacts $[139,140]$. The human fatality rate from MERS is around 30-35\% [141], while the disease is asymptomatic in infected dromedaries. In rare cases, infected dromedaries may develop mild respiratory symptoms [142]. MERS-CoV was shown to develop severe infections in the lower respiratory tract [143].

\subsection{Wild Animals and Re-Emerging Zoonoses}

Wild animals are intricately connected with humans, domesticated animals, and environmental components, and thereby directly contribute to the transmission and maintenance of different infectious diseases [144]. Globalization, habitat destruction, climatic change, and loss of species and biodiversity are disrupting the ecological relations among the one-health components, which ultimately triggers the emergence of zoonotic pathogens and causes alterations in their transmission patterns [145-147]. Pathogens carried by wild animals can impact human health and animal health, reduce agricultural production, and generate disturbance in wildlife [148].

Wild animals such as mammals, reptiles, birds, fish, and amphibians act as a reservoir of zoonotic pathogens with the potential of transmission to humans or other animal hosts. The involvement of wild animals in the epidemiology and transmission of zoonotic diseases is alarming. The transmission patterns of wildlife zoonoses are influenced by the nature of pathogen involved and climatic parameters such as temperature, humidity, and rain fall [122]. The emergence and re-emergence of these pathogens is dependent on their transmission patterns among wild animals, domestic animals, and humans. Factors impacting these processes include (1) rapid increase of the human population; (2) ease of local and global travel; (3) increased human exposure to animals and animal products; (4) wildlife farming; (5) hunting, handling, and transporting wildlife (including carcasses) with limited precautions; (6) consumption of wild meat (such as bush meat); and (7) differences in agricultural practices $[123,148,149]$.

In emerging and re-emerging diseases, there is significant transmission of pathogens to humans from wild animals. Human infections are usually developed from wild animals via direct contact or vector-mediated sources (such as in case of rabies and/or lyssaviruses, hantaviruses, Nipah virus, West Nile virus, and causative agents of leptospirosis and ehrlichiosis). The spread of infections largely depends on human-human transmission such as with HIV, Ebola virus, and coronaviruses [148]. 
Figure 1 represents the role of wild animals in the transmission, amplification, and zoonotic overflow of causal agents of emerging and re-emerging zoonoses. In many cases, the wild animals act as reservoirs of causal agents that can stay dormant for long periods until triggered. The presence of agents in unusual hosts can sometimes increase the likelihood of errors in the process of RNA replication which can lead to mutations. This can lead to the generation of newer strains or species that can be more virulent, and/or more resistant to antibiotics. Consequences can include increased transmission rates in susceptible populations [150-154].

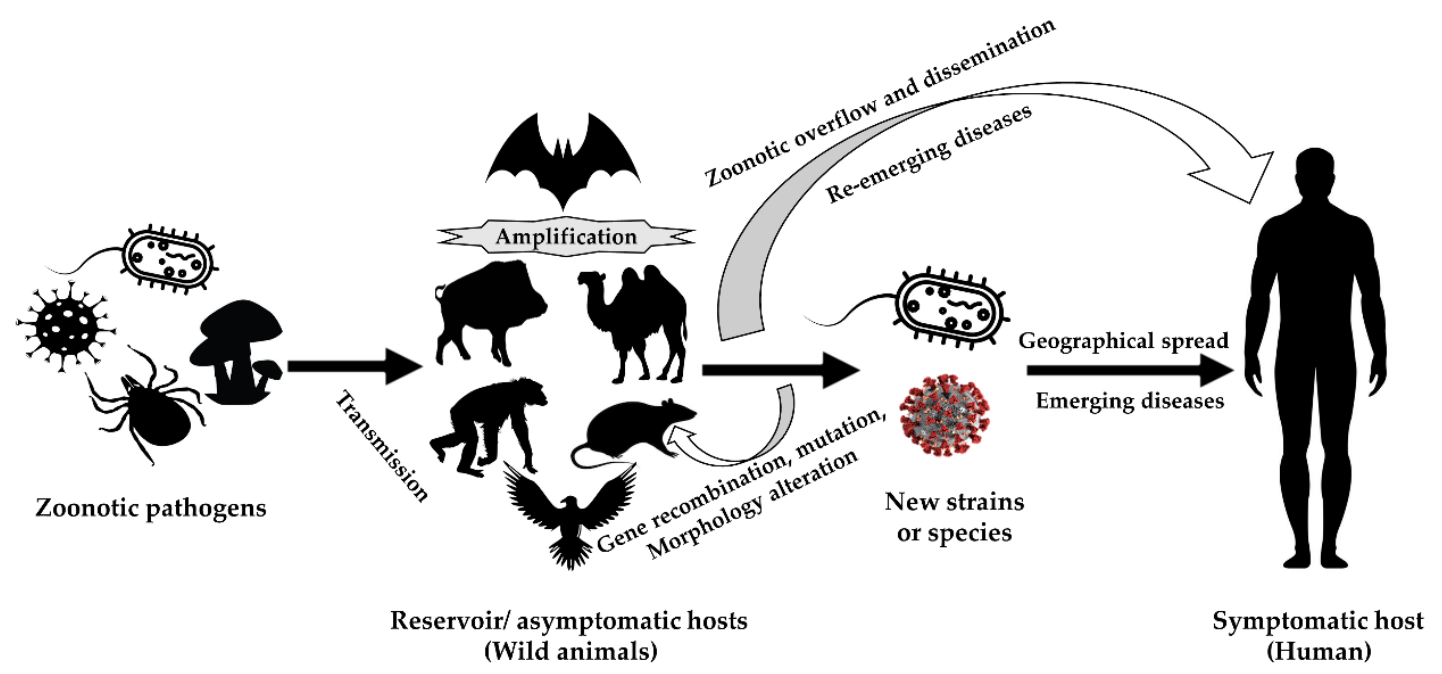

Figure 1. The involvement of the wild animals in the transmission and amplification of etiological agents of emerging and re-emerging zoonoses (modified with permission from [150]).

\subsection{Zoonotic Coronaviruses}

Coronaviruses are enveloped, positive-sense single-stranded RNA viruses of the family Coronaviridae $[155,156]$. Previously six coronaviruses (CoVs) were known to cause human infections. Recently, a newly emerged coronavirus initially known as 2019-novel coronavirus (2019-nCoV) and later designated as SARS-CoV-2, was reported from China in late December 2019 causing a disease known as COVID-19, and the outbreak has been later classified as pandemic [156-159]. All seven reported human coronaviruses are zoonotic in nature. Bat is the natural host for most coronaviruses with the exception of HCoV-OC43 and HCoV-HKU1, which have originated from rodents (Table 3). A possible route of transmission to humans is through an intermediate host that humans have contact with. As the viruses are chiefly transmitted through respiratory droplets and fomites, human to human transmission is relatively easy. Contact transmission is an important factor in tracking the spread of these viruses. Among the seven viruses, SARS-CoV, MERS-CoV, and SARS-CoV-2 were the most severe. MERS-CoV had the highest fatality rate. COVID-19 is a global public health challenge and is causing devastating effects on health, social life, and economy all over the world. The disease has been reported in more than 200 countries causing 25 million cases and 0.9 million deaths worldwide [160]. The zoonotic features of SARS-CoV-2 are presented in Figure 2. 
Table 3. Salient features of different zoonotic coronaviruses.

\begin{tabular}{|c|c|c|c|c|c|c|c|}
\hline Virus & HCoV-229E & HCoV-NL63 & HCoV-OC43 & HCoV-HKU1 & SARS-CoV & MERS-CoV & SARS-CoV-2 \\
\hline Genus & \multicolumn{3}{|c|}{ Alphacoronavirus } & & Betacoronavirus & & \\
\hline Disease & \multicolumn{3}{|c|}{ Mild respiratory tract infections } & $\begin{array}{l}\text { Mild respiratory } \\
\text { tract infections } \\
\text { and pneumonia }\end{array}$ & $\begin{array}{l}\text { Severe acute } \\
\text { respiratory } \\
\text { syndrome }\end{array}$ & $\begin{array}{l}\text { Middle East } \\
\text { respiratory } \\
\text { syndrome }\end{array}$ & $\begin{array}{l}\text { Coronavirus } \\
\text { disease } 2019\end{array}$ \\
\hline Natural host & \multicolumn{2}{|c|}{ Bats } & \multicolumn{2}{|c|}{ Rodents } & \multicolumn{3}{|c|}{ Bats } \\
\hline Intermediate host & Camelids? & Unidentified & Bovines & Unidentified & Palm civets & Dromedary camels & Unidentified \\
\hline Transmission & \multicolumn{4}{|c|}{ Respiratory droplets, aerosols, and fomites } & $\begin{array}{c}\text { Respiratory } \\
\text { droplets, aerosols, } \\
\text { fomites and } \\
\text { fecal-oral }\end{array}$ & $\begin{array}{l}\text { Respiratory } \\
\text { droplets and } \\
\text { fomites }\end{array}$ & $\begin{array}{c}\text { Respiratory } \\
\text { droplets, aerosols, } \\
\text { fomites, and } \\
\text { fecal-oral (?) }\end{array}$ \\
\hline $\begin{array}{c}\text { Incubation period } \\
\text { (days) }\end{array}$ & $2-5$ & $2-4$ & $2-5$ & $2-4$ & $2-11$ & $2-13$ & $1-14$ \\
\hline $\begin{array}{l}\text { Signs and } \\
\text { symptoms }\end{array}$ & $\begin{array}{l}\text { Fever, nasal } \\
\text { discharge, } \\
\text { sneezing, cough, } \\
\text { malaise headache, } \\
\text { and sore throat }\end{array}$ & $\begin{array}{c}\text { Fever, dry cough, } \\
\text { headache, myalgia, } \\
\text { malaise, dyspnea, } \\
\text { respiratory } \\
\text { distress, and } \\
\text { diarrhea }\end{array}$ & $\begin{array}{c}\text { Fever, nasal } \\
\text { discharge, } \\
\text { sneezing, cough, } \\
\text { malaise headache, } \\
\text { and sore throat }\end{array}$ & $\begin{array}{c}\text { Fever, cough, } \\
\text { running nose, and } \\
\text { dyspnea }\end{array}$ & $\begin{array}{l}\text { Fever, headache, } \\
\text { dry cough, } \\
\text { dyspnea, } \\
\text { respiratory } \\
\text { distress, malaise, } \\
\text { myalgia, and } \\
\text { diarrhea }\end{array}$ & $\begin{array}{l}\text { Fever, cough, } \\
\text { myalgia, chills, } \\
\text { sore throat, } \\
\text { dyspnea, } \\
\text { pneumonia, } \\
\text { arthralgia, } \\
\text { diarrhea, vomiting, } \\
\text { and acute renal } \\
\text { impairment }\end{array}$ & $\begin{array}{l}\text { Fever, dry cough, } \\
\text { headache, } \\
\text { dyspnea, myalgia, } \\
\text { respiratory } \\
\text { distress, renal } \\
\text { impairment, } \\
\text { diarrhea, multiple } \\
\text { organ failure }\end{array}$ \\
\hline Case fatality & N/A & N/A & N/A & N/A & $9.6 \%$ & $34.4 \%$ & $3.5 \%$ \\
\hline Epidemiology & & Peak in wir & ter globally & & $\begin{array}{c}2002-03 \text { in China, } \\
\text { then Globally to } 29 \\
\text { countries }\end{array}$ & $\begin{array}{c}2012 \text { in Middle } \\
\text { East, } \\
2015 \text { in South } \\
\text { Korea, and } \\
\text { Endemic in } \\
\text { Middle East }\end{array}$ & $\begin{array}{l}\text { 2019-2020 in } \\
\text { China, then } \\
\text { progressed to a } \\
\text { global pandemic. }\end{array}$ \\
\hline References & [161-167] & [168-173] & {$[165,174]$} & {$[174,175]$} & [176-183] & [184-196] & [155,197-199] \\
\hline
\end{tabular}




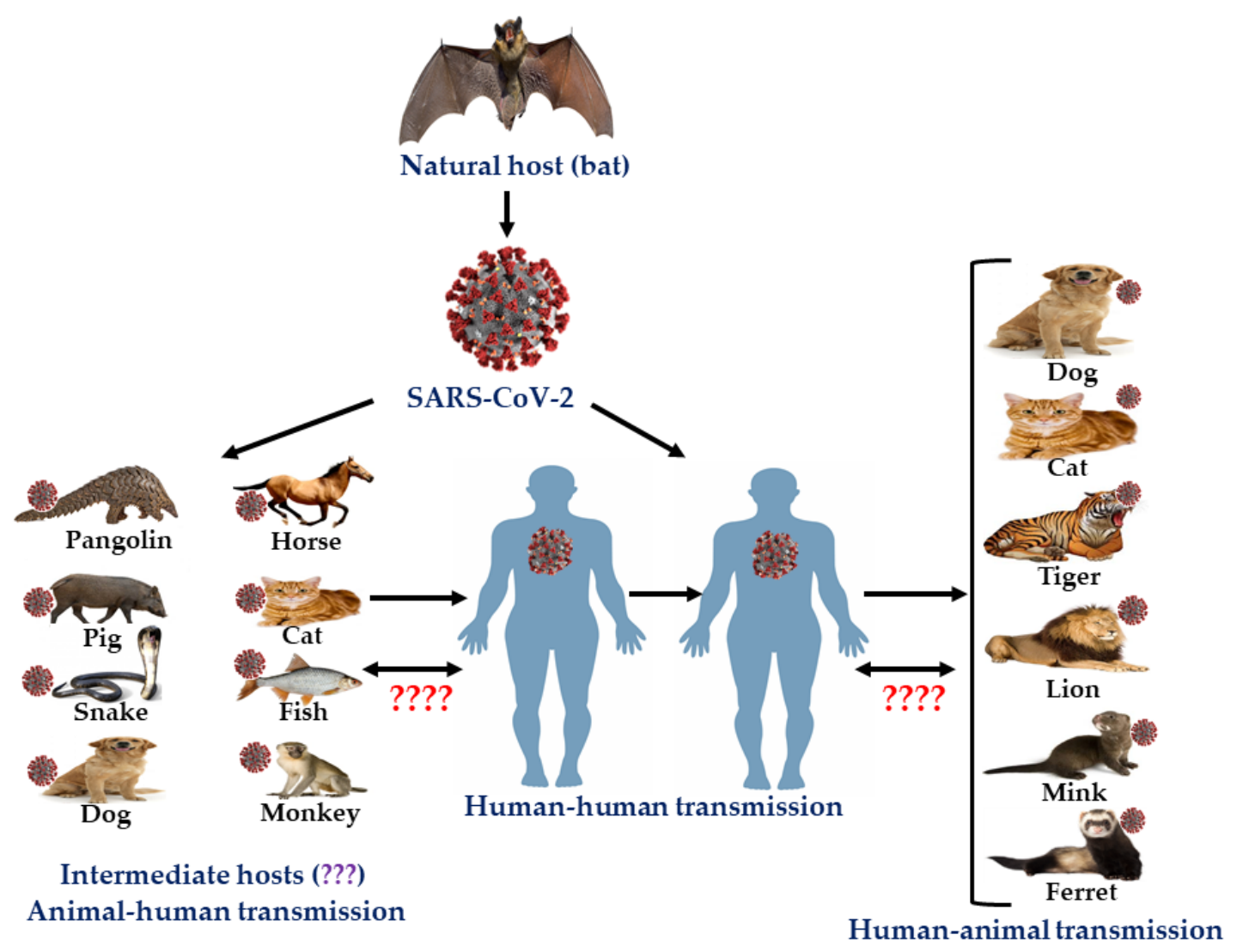

Figure 2. Zoonotic features of SARS-CoV-2 (modified with permission from [200]).

\section{Neglected Zoonoses}

Many zoonotic diseases are endemic in the developing world, which negatively impacts the health conditions and livelihoods of poor people. Because of their endemic nature, they tend to be under-reported and have been largely neglected by many funding agencies compared to emerging and re-emerging zoonoses and thus have been named as neglected zoonoses [201]. Most developed countries have been successful in the control and elimination of neglected zoonotic diseases [202]. The salient features of neglected zoonoses are presented in Figure 3.

Mainly, tropical countries are more vulnerable for neglected diseases, which is why these diseases have been sometimes known as neglected tropical diseases. Since the neglected zoonotic diseases have lower priority in the health systems in many countries, they have silently triggered significant morbidity among rural people. In May 2013, delegations from 32 WHO member states made some important decisions in the "World Health Assembly" to attempt to control 17 neglected zoonotic diseases. They also implemented a WHO roadmap for the assessment of preventive and control strategies for those neglected tropical diseases [203]. Important zoonotic diseases include rabies, anthrax, cysticercosis, brucellosis, foodborne trematode infections, leishmaniasis, echinococcosis, and zoonotic sleeping sickness [204,205]. Zoonotic diseases that have been neglected (neglected zoonoses) include rabies in Africa and Asia; echinococcosis and taeniasis (Taenia solium) in Asia, Africa, and Latin America; leishmaniasis in Asia and Africa; and cysticercosis and foodborne trematodiasis in Africa [206]. 


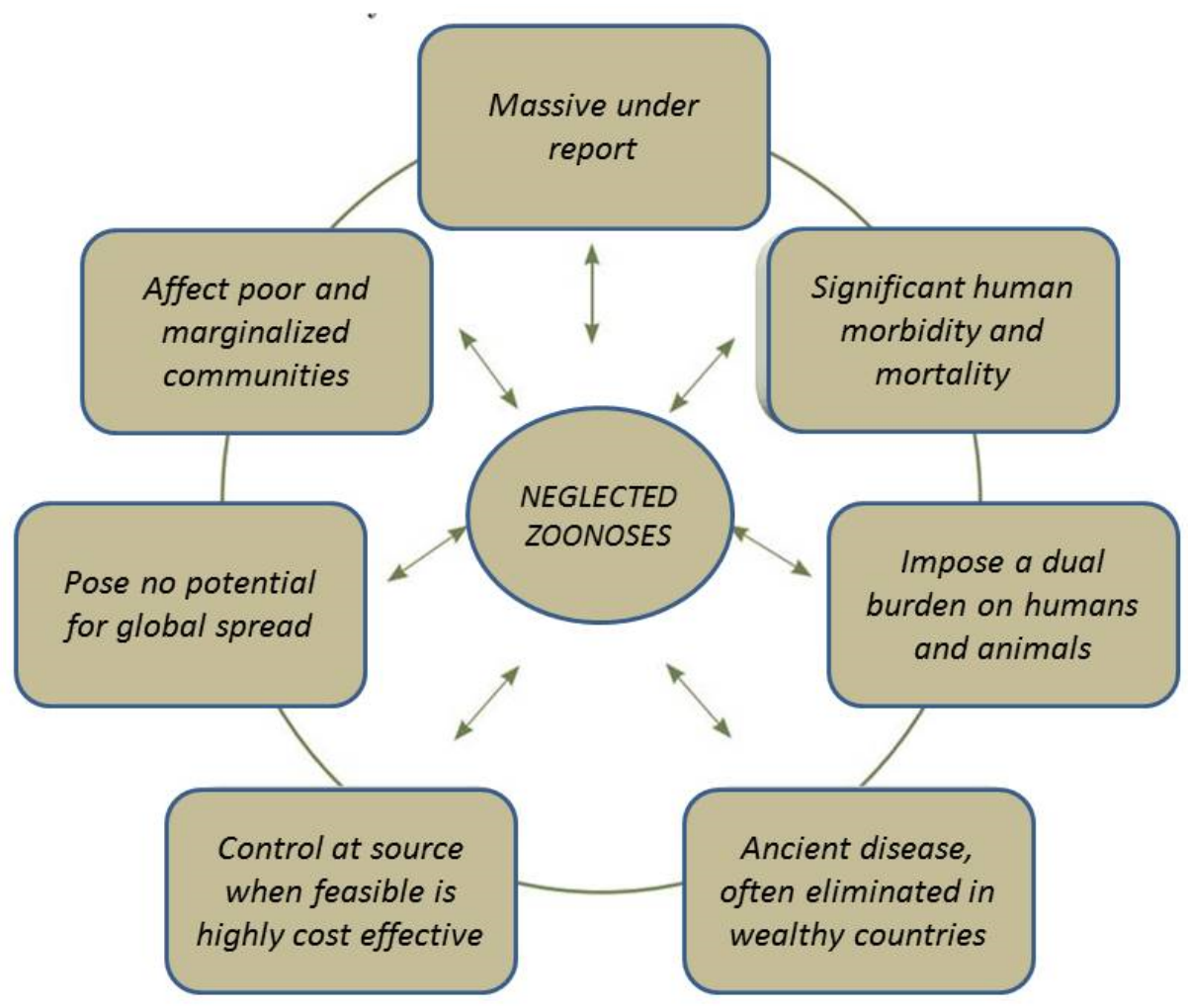

Figure 3. Basic features of neglected zoonotic diseases (reproduced with permission from [202]).

\section{Impact of Zoonoses}

Zoonoses have myriad impacts on human and animal health. Though the impact of zoonoses is hard to quantify, it can be assessed by parameters such as disease prevalence, incidence, morbidity, mortality, and economic loss [207]. Both human livelihood and well-being are severely affected by zoonoses. The affected individuals suffer from hurdles that negatively impact their work performance and thus their ability to support their families. These situations are frequently noticed in under-developed African and Asian countries. In some cases, the affected individuals may stay isolated from the rest of the community and thus are more prone to developing mental health issues. Antibiotic resistance is a global health challenge that can negatively impact the treatment of bacterial zoonoses. Patients suffering from diseases caused by resistant bacteria need special attention, expensive medicine, and are generally a burden on the health sector, especially in developing countries.

Animal deaths caused by zoonotic diseases can impose massive economic losses on the livestock sector of any country. Even if animals do not die, animal health and productivity can still be negatively impacted. This can lead to a significant loss of animal products such as meat, milk, and eggs, which can be more than $70 \%$. Human health and nutrition are also affected due to the reduced supply of high-protein food of animal origin such as milk, meat, and eggs [208]. Zoonotic diseases, such as brucellosis, toxoplasmosis, can lead to infertility, abortion, and weak offspring. This can cause great economic losses to farmers and to the whole country.

Zoonotic diseases such as BSE, avian influenza, and anthrax can hamper the international trade of animals and animal products (meat, milk, and eggs) and byproducts across the globe. The economy is also tremendously affected due to measures required for zoonoses control and eradication such as zoonoses surveillance, diagnosis, isolation and quarantine, restriction on animal transportation, treatment and vaccination programs, inspection of meat and milk, and biosecurity. From 1995 to 2008, the global economic impact of zoonotic outbreaks has exceeded 120 billion USD [209]. In the UK, the economic losses due to zoonotic diseases were significant [210]. In 2007, the UK faced drastic food-borne pathogen problem by Campylobacter spp., Salmonella (non-typhoidal), E. coli VTEC 
O157, Listeria monocytogenes, and norovirus, which caused serious economic losses [211]. In addition, other countries also faced drastic economic losses due to outbreaks of zoonotic food-borne pathogens. For example, Ireland has also suffered a severe economic loss due to Salmonella contamination in its pork products [211]. According to the World Bank [212], Australia has lost 16\% of the value of its livestock sector due to outbreaks that impacted beef and sheep. [213].

It is noteworthy that the global economy was severely impacted by the SARS outbreak, which impacted multiple sectors including the tourism sector. The economic impact of SARS in Singapore, China, Hong Kong, and Taiwan was severe [214]. Moreover, the emergence of the highly pathogenic avian influenza significantly curtailed tourism to Mexico and resulted in economic losses to the country [215]. Likewise, India faced economic losses due to the restriction of tourism that resulted from the plague outbreak in 1994 [214]. Furthermore, Chile has suffered steep economic losses due to the outbreak of highly pathogenic avian influenza [216]. Countries in the European Union were not spared from drastic economic losses resulting from the closure of export markets of poultry during the outbreak of highly pathogenic avian influenza [211].

BSE is one of the important emerging zoonoses. When outbreaks of BSE occurred in the UK, most European countries banned importing British beef. The cost for implementing extensive control measures, including culling of all infected cattle and slaughter of at-risk animals, was exorbitant [217]. The outbreak of BSE in Toronto, Canada, resulted in the loss of $0.5 \%$ of the city's GDP. The disease was detected in millions of animals for which many countries banned international trade with Canada [218]. Due to the detection of BSE in the U.S. in 2003, numerous countries banned the import of American beef causing drastic economic losses [219].

Brucellosis is another economically-important zoonoses. Brucellosis in cattle resulted in annual economic losses in Kenya [220], Argentina [221], and Nigeria [222]. The recent COVID-19 outbreak has significantly impacted the global economy. COVID-19 has significantly impacted all sectors of the society including health and education sectors, financial sectors, travel and hospitality sectors, and the sports sector [223]. Travel industry is poised to lose significant revenue due to the pandemic [223]. It is estimated that millions of people will face extreme poverty due to the stalled growth resulting from this pandemic [224].

The disease burdens associated with zoonoses are presented in Table 4. As revealed from the table, emerging zoonoses are mostly concentrated in more developed countries whereas endemic zoonoses are mostly located in developing countries.

Table 4. Disease burdens associated with zoonoses (retrieved from [6,225]).

\begin{tabular}{|c|c|c|c|c|c|c|}
\hline \multicolumn{2}{|c|}{ Poverty Interface } & \multicolumn{2}{|c|}{ Emerging Market Interface } & \multicolumn{3}{|c|}{ Zoonoses Interface } \\
\hline $\begin{array}{l}\text { Poor livestock } \\
\text { Keepers }\end{array}$ & $\begin{array}{l}\text { Protein Energy } \\
\text { Malnutrition }\end{array}$ & $\begin{array}{l}\text { Monogastrics } \\
\text { (TLU) } 2010\end{array}$ & $\begin{array}{c}\text { Rapid Change } \\
\text { Monogastrics 2010-2030 }\end{array}$ & $\begin{array}{c}\text { Zoonoses } \\
\text { Burden (GBD) }\end{array}$ & $\begin{array}{l}\text { Endemic Zoonoses } \\
\text { Prevalence }\end{array}$ & $\begin{array}{c}\text { Emerging } \\
\text { Zoonoses Events }\end{array}$ \\
\hline Bangladesh & Bangladesh & Bangladesh & Myanmar & India & Nigeria & USA \\
\hline India & India & India & Burkina Faso & Nigeria & Ethiopia & UK \\
\hline Pakistan & Pakistan & Pakistan & India & Congo DR & Tanzania & Australia \\
\hline China & China & Myanmar & Pakistan & China & Togo & France \\
\hline Kenya & Ethiopia & China & Ghana & Ethiopia & India & Brazil \\
\hline Nigeria & Nigeria & Thailand & Afghanistan & Bangladesh & Mali & Canada \\
\hline Sudan & Indonesia & Indonesia & Bangladesh & Pakistan & Vietnam & Germany \\
\hline Congo DR & Congo DR & Vietnam & Liberia & Afghanistan & Sudan & Japan \\
\hline Ethiopia & Angola & Iran & $\begin{array}{c}\text { Central African Republic } \\
\text { Chad } \\
\text { Cambodia }\end{array}$ & Angola & Bangladesh & China \\
\hline Tanzania & Afghanistan & Philippines & Benin & Brazil & Burkina Faso & Sweden \\
\hline Turkey & Sudan & Brazil & Laos & Indonesia & Cameroon & Italy \\
\hline Indonesia & Philippines & Nigeria & Thailand & Niger & Chad & Malaysia \\
\hline Niger & Brazil & Peru & Zimbabwe & Tanzania & Rwanda & Switzerland \\
\hline
\end{tabular}


Table 4. Cont.

\begin{tabular}{|c|c|c|c|c|c|c|}
\hline \multicolumn{2}{|c|}{ Poverty Interface } & \multicolumn{2}{|c|}{ Emerging Market Interface } & \multicolumn{3}{|c|}{ Zoonoses Interface } \\
\hline $\begin{array}{l}\text { Poor livestock } \\
\text { Keepers }\end{array}$ & $\begin{array}{l}\text { Protein Energy } \\
\text { Malnutrition }\end{array}$ & $\begin{array}{l}\text { Monogastrics } \\
\text { (TLU) } 2010\end{array}$ & $\begin{array}{c}\text { Rapid Change } \\
\text { Monogastrics 2010-2030 }\end{array}$ & $\begin{array}{c}\text { Zoonoses } \\
\text { Burden (GBD) }\end{array}$ & $\begin{array}{l}\text { Endemic Zoonoses } \\
\text { Prevalence }\end{array}$ & $\begin{array}{c}\text { Emerging } \\
\text { Zoonoses Events }\end{array}$ \\
\hline Uganda & Uganda & South Africa & & Kenya & Ghana & Congo DR \\
\hline Madagascar & Mali & Morocco & $\begin{array}{l}\text { Ethiopia } \\
\text { Guinea }\end{array}$ & $\begin{array}{l}\text { Côte d'Ivoire } \\
\text { Uganda }\end{array}$ & Mozambique & Sudan \\
\hline Philippines & South Africa & Ecuador & Guinea-Bissau & Sudan & South Africa & Argentina \\
\hline Afghanistan & Vietnam & Colombia & China & Burkina Faso & Congo DR & India \\
\hline Egypt & Tanzania & Ukraine & Mali & Mali & Egypt & Israel \\
\hline Mozambique & Mozambique & Bolivia & & Iraq & Gambia & Peru \\
\hline \multirow[t]{2}{*}{ Burkina Faso } & Malawi & Egypt & & & Ivory Coast & $\begin{array}{c}\text { Trinidad and } \\
\text { Tobago } \\
\text { Uganda }\end{array}$ \\
\hline & & & & & $\begin{array}{l}\text { Pakistan } \\
\text { Zimbabwe }\end{array}$ & Vietnam \\
\hline
\end{tabular}

Here, TLU = Tropical Livestock Units; GBD = Global Burden of Disease.

\section{Control of Zoonoses}

Zoonoses present a serious health threat to the international community. About $58-61 \%$ of the human diseases are communicable and up to $75 \%$ are zoonotic (transmitted from animals) $[226,227]$. Zoonosis involves the interaction of humans, animals, and environment, and therefore a multi-sectorial approach is required to ensure effective control measures [228].

Surveillance is crucial to prevent and control zoonotic diseases. It can be used to detect early infection, affected humans and animals, reservoirs, vectors, and endemic areas including the "hotspots". It helps in the adaptation of control strategies against emerging and re-emerging diseases to improve human health status, to manage disease properly, and to minimize morbidity and mortality of humans and animals. Since zoonoses (such as SARS and HPAI) can spread swiftly across the globe to affect global communities, coordinated surveillance approaches at local, regional, national, and international levels are essential to control zoonoses. All potential sources of zoonoses including exotic animals and birds, pet and companion animals, aquatic animals, wildlife, and rodents need to be subject to surveillance. There are different types of surveillance that need to be conducted [229]. Successful and functional surveillance requires well equipped lab, adequate diagnostic facilities, skilled manpower and funding. The following four surveillance types can be practiced for the control of zoonoses:

- Pathogen surveillance to detect and identify pathogens.

- Serological surveillance to detect the presence of pathogens in the blood of humans or animals through monitoring immune responses.

- Syndrome surveillance to determine the propensity of diseases through data analysis based on symptoms. This analysis-based surveillance cannot be used identify the presence of pathogens.

- Risk surveillance to detect risk factors responsible for the transmission of disease. This control strategy cannot be used to determine the clinical features of multifarious diseases along with their prevalence.

General principals of disease control such as providing treatment to affected individuals, vaccination of healthy individuals and animals, restricting animal movement, animal population control, and test and cull (anthrax, glanders, and Rift Valley fever) can also be used for the control of zoonoses. Decontamination of infected materials is needed to reduce the chances of acquiring new infections. For example, safe disposal of aborted fetus can reduce the prevalence of brucellosis. Personal hygienic management and usage of personal protective equipment such as gloves, masks, lab coats, helmets, and goggles need to be practiced. When applicable, thorough disinfection of contaminated materials and areas need to be carried out to assist in reducing the spread of brucellosis, salmonellosis, and tuberculosis.

Concerted and multidisciplinary approaches are required for the control of emerging and re-emerging zoonoses [230]. Many emerging and re-emerging infections (such as dengue fever, Zika, and chikungunya) are vector-borne arboviral infections. Therefore, for their effective control, 
an effective epidemiological surveillance of these infections needs to be taken under consideration in addition to vector control [231]. This surveillance includes risk factors responsible for emergence or re-emergence such as vector biology, host dynamics, pathogen niche and virulence, wildlife distribution, land use, and socio-economic status. Pest and vector control are also required to control some parasitic and bacterial zoonoses transmitted by vector-like mosquitoes, tick, and lice. Successful vector control strategies should contain a combination of physical, biological, and/or mechanical methods including integrated pest management and integrated vector management systems [232].

Many zoonoses are preventable but are neglected despite being a significant threat on public health, especially in developing countries. During zoonoses control programs, factors relating to both humans and animals need to be accounted for. Where several neighboring countries are affected, coordinated approaches need to be adopted for zoonoses control. Approaches that rely on the principles of one health policies need to be adopted and must involve veterinarians, medical doctors, occupational health physicians and public health operators, conservation officers and environmental officers for effective zoonoses control [233]. A research project named Integrated Control of Neglected Zoonoses for the control of neglected zoonotic diseases in Africa reinforced the one health-based concepts among academic and professionals from 21 European and African countries [234].

All disease control measures require a substantial amount of financial support that is usually unavailable for the developing countries. The developed countries and international donors need to support the developing countries for effective zoonoses control. Donor agencies such as WHO, Food and Agriculture Organization of the United Nations (FAO), World Organization for Animal Health (OIE), US Agency for International Development (USAID), US Department of Agriculture (USDA), European Union (EU), Department for International Development (DFID), Biotechnology and Biological Sciences Research Council (BBSRC), and Danish International Development Agency (DANIDA) could be approached for funding. Similarly, private funding bodies like the Welcome Trust and the Bill and Melinda Gates Foundation can also be approached for funding to implement zoonoses control programs [235].

In order to control food-borne zoonoses, an ample supply of safe food has to be made available for consumers. This could be achieved through implementing two broad approaches: risk assessment and risk management of food products. Risk assessment can be conducted through collecting and analyzing data, and by providing recommendations based on importance; risk management should be adopted by taking legislative measures and setting targets to reduce the risk. Animal-origin foods such as meat, milk, and eggs have to originate from healthy animals that are free of zoonotic pathogens. Proper ante-mortem and post-mortem examination of animals is vital to ensure safety of food from animal origin. Ensuring hygienic conditions in every step of food processing including personal hygiene of personnel involved in food processing need to be monitored for the production of safe food.

Other activities for the control of zoonoses include issuing laws and regulations related to the isolation and quarantine, establishment strong and effective disease reporting (notification) systems, farm biosecurity, mass vaccination, test and slaughter or cull, public awareness, and health education. Mass media and electronic information system, social networks, text messages and other communication channels can play a significant role in increasing public awareness to control zoonoses.

\section{Zoonoses and One Health}

For the prevention and control of infectious diseases such as zoonotic diseases, international organizations and researchers described the relationship among human, animals, and environments and adopted a concept known as "One Health Concept" or "One Health Approach". This concept was adopted to properly deal with global health challenges [225]. The one health concept encourages collaborations among wildlife biologists, veterinarians, physicians, agriculturists, ecologists, microbiologists, epidemiologists, and biomedical engineers to ensure favorable health for animals, humans, and our environment $[228,236,237]$. The one health approach has widespread impacts on 
poverty, food security, and health security through the prevention and control of zoonoses, mainly in the developing countries [238].

For the prevention and control of emerging and re-emerging diseases including zoonoses, the collaborations and partnerships of multi-sectoral personnel are badly needed for the implementation of feasible operations and surveillance among the human, animals, and environmental sectors [236]. WHO, OIE, FAO, US Centers for Disease Control and Prevention (CDC), US Department of Agriculture (USDA), United Nations System Influenza Coordination (UNSIC), and European Commission recognize the prevention and control strategies involving the one health approach [239-241].

One health is directly linked in the prevention and control of zoonoses. According to Pieracci et al. [242], the recommendations provided by one health approach to prevent and control zoonoses are (1) developing "Zoonotic Disease Unit" for betterment of the human and animal health agencies; (2) developing national strategy for "Zoonotic Disease Unit"; (3) engaging leadership among multi-sectoral researchers and relevant personnel to prioritize zoonotic disease research; (4) adopting veterinary public health policies with collaborators from other countries; and (5) reviewing the zoonotic diseases on a regular basis ( $2-5$ years) to address the emerging and re-emerging diseases through regular surveillance, epidemiological implementations, and laboratory diagnosis.

Experts from CDC's one health office have suggested some strategies in the One Health Zoonotic Disease Prioritization to prevent and control zoonotic diseases [239]. The recommendations include (1) developing a list of emerging and re-emerging zoonotic diseases based on priority by the delegated one health sectors; (2) implementing recommendations for further steps to reduce the intensification of diseases; (3) realizing the role and importance among represented one health sectors; (4) strengthening and creating the one health coordination programs; and (5) generating reports on zoonotic diseases on national, subnational, and regional levels.

In brief, the one health concept plays a significant role to address emerging and re-emerging zoonoses; to control the effect of zoonotic diseases among humans, animals, and environmental components; and to make the world free from threats of zoonotic diseases.

\section{Recommendations}

Zoonotic diseases represent a serious public health concern. Many zoonoses are currently under control but there is gap in our knowledge about many diseases especially on the disease distribution, etiology, pathogen, host, vector biology, dynamics, transmission cycle, predisposing factors, and risk factors. The equilibrium exists among the host, agent, and environment may be disturbed at any point due to various anthropogenic activities of increasing human population and natural activities to evoke emission of zoonoses. With the existing knowledge we cannot accurately predict the time or the impact of the next pandemic of a zoonoses may occur. The following activities need to be ensured or strengthened for our preparedness to overcome such pandemic.

- Active and wider zoonoses surveillance and monitoring with advanced tools like satellite-based remote sensing system and molecular epidemiological tools.

- Disease reporting and notification service.

- Giving priority to zoonoses and action team formation.

- Available diagnostic facilities and skilled manpower.

- Cooperation at regional, national, subnational, and international levels.

- One health-based approach comprising both veterinarians and medical doctors in addition to environmental experts and other professionals.

- Ensuring adequate regular and emergency funding.

- Mass campaigning on public awareness on zoonoses.

- More research on disease epidemiology, risk factors, pathogen virulence, host biology, and vector biology.

- Wildlife monitoring and wildlife protection. 
- Ensure safe food production of animal origin.

- Ensure safety of infectious laboratories to avoid the accidental spread of zoonotic infections and bioterrorism.

- Protection of environment.

- National and international educational programs to make people aware of zoonoses and hygiene.

\section{Conclusions}

The majority of the human infectious diseases have animal origins. These pathogens do not only cause diseases in animals, but they also pose a serious threat for human health. In many cases the altered food habit, climate change, and environmentally unfriendly human operations influence the emergence and reemergence of many zoonotic diseases because of the increased contact between humans and wild animals. The devastating impact of zoonosis on the human population is evident from the current COVID-19 pandemic. Because of the strong interrelatedness among animals, humans, and environment; research focusing on the one health approach need to be prioritized to identify critical intervention steps in the transmission of pathogens. Robust active surveillance targeting all components of the one health approach need to be implemented to early and accurately detect zoonoses, so that effective control measures could be taken.

Author Contributions: Conceptualization, M.T.R., A.M.M.T.R., M.E.E.Z., and H.M.A.; literature collection and curation, M.T.R., M.A.S., M.S.I., S.I., and H.M.A.; writing-original draft, M.T.R., M.A.S., M.S.I., S.I., M.J.H., M.E.E.Z., and H.M.A.; and writing-review and editing, M.T.R., M.E.E.Z., and H.M.A. All authors have read and agreed to the published version of the manuscript.

Funding: This research received no external funding.

Acknowledgments: We are grateful to late Professor Md. Abdur Rahman, Consultant Veterinarian, Veterinary Teaching Hospital, Bangladesh Agricultural University, for his valuable comments and suggestions.

Conflicts of Interest: The authors declare no conflict of interest.

\section{References}

1. Thompson, A.; Kutz, S. Introduction to the Special Issue on 'Emerging Zoonoses and Wildlife'. Int. J. Parasitol. Parasites Wildl. 2019, 9, 322. [CrossRef]

2. World Health Organization. Asia Pacific Strategy for Emerging Diseases: 2010. Manila: WHO Regional Office for the Western Pacific. Available online: https://iris.wpro.who.int/bitstream/handle/10665.1/7819/ 9789290615040_eng.pdf (accessed on 20 July 2020).

3. Slingenbergh, J. World Livestock 2013: Changing Disease Landscapes; Food and Agriculture Organization of the United Nations (FAO): Rome, Italy, 2013; p. 2.

4. World Health Organization. WHO Health Topic Page: Zoonoses. Available online: https://www.who.int/ topics/zoonoses/en/ (accessed on 20 July 2020).

5. Taylor, L.H.; Latham, S.M.; Woolhouse, M.E. Risk factors for human disease emergence. Philos. Trans. R. Soc. Lond. B Biol. Sci. 2001, 356, 983-989. [CrossRef] [PubMed]

6. Grace, D.; Mutua, F.; Ochungo, P.; Kruska, R.; Jones, K.; Brierley, L.; Lapar, L.; Said, M.; Herrero, M.; Phuc, P.M.; et al. Mapping of poverty and likely zoonoses hotspots. In Zoonoses Project 4 . Report to the UK Department for International Development; International Livestock Research Institute: Nairobi, Kenya, 2012.

7. Chomel, B.B. Zoonoses. In Encyclopedia of Microbiology, 3rd ed.; Elsevier Inc., University of California: Davis, CA, USA, 2009; pp. 820-829.

8. Hubálek, Z. Emerging human infectious diseases: Anthroponoses, zoonoses, and sapronoses. Emerg. Infect. Dis. 2003, 9, 403-404. [CrossRef]

9. McDaniel, C.J.; Cardwell, D.M.; Moeller, R.B.; Gray, G.C. Humans and cattle: A review of bovine zoonoses. Vector Borne Zoonotic Dis. 2014, 14, 1-19. [CrossRef] [PubMed]

10. Bae, S.E.; Son, H.S. Classification of viral zoonosis through receptor pattern analysis. BMC Bioinform. 2011, 12, 96. [CrossRef] [PubMed]

11. Mortimer, P.P. Influenza: The centennial of a zoonosis. Rev. Med. Virol. 2019, 29, e2030. [CrossRef] 
12. Huang, Y.J.S.; Higgs, S.; Vanlandingham, D.L. Arbovirus-mosquito vector-host interactions and the impact on transmission and disease pathogenesis of arboviruses. Front. Microbiol. 2019, 10, 22. [CrossRef]

13. Pavlovsky, E.N. Natural Nidality of Transmissible Diseases with Special Reference to the Landscape Epidemiology of Zooanthroponoses; University of Illinois Press: Champaign, IL, USA, 1966.

14. Beaty, B.J.; Marquardt, W.C. The Biology of Disease Vector; University Press of Colorado: Niwot, CO, USA, 1996.

15. Somov, G.P.; Litvin, V.J. Saprophytism and Parasitism of Pathogenic Bacteria-Ecological Aspects; Nauka: Novosibirsk, Russia, 1988. (In Russian)

16. Schwabe, C.W. Veterinary medicine and human health. In Veterinary Medicine and Human Health; The Williams \& Wilkins Company, 428 E. Preston St.: Baltimore, MD, USA, 1964.

17. Olayemi, A.; Adesina, A.S.; Strecker, T.; Magassouba, N.F.; Fichet-Calvet, E. Determining Ancestry between Rodent-and Human-Derived Virus Sequences in Endemic Foci: Towards a More Integral Molecular Epidemiology of Lassa Fever within West Africa. Biology 2020, 9, 26. [CrossRef]

18. Cerdà-Cuéllar, M.; Moré, E.; Ayats, T.; Aguilera, M.; Muñoz-González, S.; Antilles, N.; Ryan, P.G.; González-Solís, J. Do humans spread zoonotic enteric bacteria in Antarctica? Sci. Total Environ. 2019, 654, 190-196. [CrossRef]

19. Adesokan, H.K.; Akinseye, V.O.; Streicher, E.M.; Van Helden, P.; Warren, R.M.; Cadmus, S.I. Reverse zoonotic tuberculosis transmission from an emerging Uganda I strain between pastoralists and cattle in South-Eastern Nigeria. BMC Vet. Res. 2019, 15, 1-7. [CrossRef]

20. Messenger, A.M.; Barnes, A.N.; Gray, G.C. Reverse zoonotic disease transmission (zooanthroponosis): A systematic review of seldom-documented human biological threats to animals. PLoS ONE 2014, 9, e89055. [CrossRef] [PubMed]

21. County of Los Angeles Public Health. Overview of Zoonoses. Available online: http://www.lapublichealth. org/vet/guides/vetzooman.htm (accessed on 20 July 2020).

22. Morand, S.; McIntyre, K.M.; Baylis, M. Domesticated animals and human infectious diseases of zoonotic origins: Domestication time matters. Infect. Genet. Evol. 2014, 24, 76-81. [CrossRef] [PubMed]

23. McNeill, W.H. Plagues and People; Anchor Press: New York, NY, USA, 1976.

24. Klous, G.; Huss, A.; Heederik, D.J.; Coutinho, R.A. Human-livestock contacts and their relationship to transmission of zoonotic pathogens, a systematic review of literature. One Health 2016, 2, 65-76. [CrossRef] [PubMed]

25. Pearce-Duvet, J.M. The origin of human pathogens: Evaluating the role of agriculture and domestic animals in the evolution of human disease. Biol. Rev. 2006, 81, 369-382. [CrossRef]

26. Samad, M.A. Public health threat caused by zoonotic diseases in Bangladesh. Bangladesh J. Vet. Med. 2011, 9 , 95-120. [CrossRef]

27. Ghasemzadeh, I.; Namazi, S.H. Review of bacterial and viral zoonotic infections transmitted by dogs. J. Med. Life 2015, 8, 1-5.

28. Goel, A.K. Anthrax: A disease of biowarfare and public health importance. World J. Clin. Cases 2015, 3, $20-33$. [CrossRef]

29. Kamal, S.M.; Rashid, A.K.; Bakar, M.A.; Ahad, M.A. Anthrax: An update. Asian Pac. J. Trop. Biomed. 2011, 1, 496-501. [CrossRef]

30. Torgerson, P.R.; Torgerson, D.J. Public health and bovine tuberculosis: What's all the fuss about? Trends Microbiol. 2010, 18, 67-72. [CrossRef]

31. Bayraktar, B.; Bulut, E.; Barış, A.B.; Toksoy, B.; Dalg1c, N.; Celikkan, C.; Sevgi, D. Species distribution of the Mycobacterium tuberculosis complex in clinical isolates from 2007 to 2010 in Turkey: A prospective study. J. Clin. Microbiol. 2011, 49, 3837-3841. [CrossRef]

32. Bayraktar, B.; Togay, A.; Gencer, H.; Kockaya, T.; Dalgic, N.; Bulut, E. Mycobacterium caprae causing lymphadenitis in a child. Pediatr. Infect. Dis. J. 2011, 30, 1012-1013. [PubMed]

33. Moda, G.; Daborn, C.J.; Grange, J.M.; Cosivi, O. The zoonotic importance of Mycobacterium bovis. Tuber. Lung Dis. 1996, 77, 103-108. [CrossRef]

34. Ocepek, M.; Pate, M.; Žolnir-Dovč, M.; Poljak, M. Transmission of Mycobacterium tuberculosis from human to cattle. J. Clin. Microbiol. 2005, 43, 3555-3557. [CrossRef]

35. Hull, N.C.; Schumaker, B.A. Comparisons of brucellosis between human and veterinary medicine. Infect. Ecol. Epidemiol. 2018, 8, 1500846. [CrossRef] 
36. WHO. The Control of Neglected Zoonotic Diseases: From Advocacy to Action: Report of the Fourth International Meeting Held at WHO Headquarters, Geneva, Switzerland, 19-20 November 2014; World Health Organization: Geneva, Switzerland, 2015; p. 44.

37. Corbel, M.J.; Alton, G.G.; Banai, M.; Díaz, R.; Dranovskaia, B.A.; Elberg, S.S.; Garin-Bastuji, B.; Kolar, J.; Mantovani, A.; Mousa, A.M.; et al. Brucellosis in Humans and Animals; WHO Press: Geneva, Switzerland, 2006.

38. Rahman, M.S.; Han, J.C.; Park, J.; Lee, J.H.; Eo, S.K.; Chae, J.S. Prevalence of brucellosis and its association with reproductive problems in cows in Bangladesh. Vet. Rec. 2006, 159, 180-182. [CrossRef] [PubMed]

39. Krebs, J.W.; Mandel, E.J.; Swerdlow, D.L.; Rupprecht, C.E. Rabies surveillance in the United States during 2003. J. Am. Vet. Med. Assoc. 2004, 225, 1837-1849. [CrossRef]

40. Tang, X.; Luo, M.; Zhang, S.; Fooks, A.R.; Hu, R.; Tu, C. Pivotal role of dogs in rabies transmission, China. Emerg. Infect. Dis. 2005, 11, 1970-1972. [CrossRef]

41. Liu, Q.; Wang, X.; Liu, B.; Gong, Y.; Mkandawire, N.; Li, W.; Fu, W.; Li, L.; Gan, Y.; Shi, J.; et al. Improper wound treatment and delay of rabies post-exposure prophylaxis of animal bite victims in China: Prevalence and determinants. PLoS Neglect. Trop. Dis. 2017, 11, e0005663. [CrossRef]

42. World Health Organization. Rabies vaccines: WHO position paper. Wkly. Epidemiol. Rec. 2018, 93, $201-220$.

43. Ghosh, S.; Rana, M.S.; Islam, M.K.; Chowdhury, S.; Haider, N.; Kafi, M.A.H.; Ullah, S.M.; Shah, M.R.A.; Jahan, A.A.; Mursalin, H.S.; et al. Trends and clinico-epidemiological features of human rabies cases in Bangladesh 2006-2018. Sci. Rep. 2020, 10,1-11. [CrossRef]

44. Plotkin, S.; Orenstein, W.; Offit, P.; Edwards, M.K. Vaccine. In Plotkin's Vaccines, 7th ed.; Elsevier: Philadelphia, PA, USA, 2017; pp. 918-942.

45. Jackson, A.C. Human rabies: A 2016 update. Curr. Infect. Dis. Rep. 2016, 18, 38. [CrossRef] [PubMed]

46. Mitrabhakdi, E.; Shuangshoti, S.; Wannakrairot, P.; Lewis, R.A.; Susuki, K.; Laothamatas, J.; Hemachudha, T. Difference in neuropathogenetic mechanisms in human furious and paralytic rabies. J. Neurol. Sci. 2005, 238, 3-10. [CrossRef] [PubMed]

47. Hemachudha, T.; Laothamatas, J.; Rupprecht, C.E. Human rabies: A disease of complex neuropathogenetic mechanisms and diagnostic challenges. Lancet Neurol. 2002, 1, 101-109. [CrossRef]

48. Dimaano, E.M.; Scholand, S.J.; Alera, M.T.P.; Belandres, D.B. Clinical and epidemiological features of human rabies cases in the Philippines: A review from 1987 to 2006. Int. J. Infect. Dis. 2011, 15, e495-e499. [CrossRef] [PubMed]

49. Chomel, B.B.; Sun, B. Zoonoses in the bedroom. Emerg. Infect. Dis. 2011, 17, 167-172. [CrossRef]

50. Halsby, K.D.; Walsh, A.L.; Campbell, C.; Hewitt, K.; Morgan, D. Healthy animals, healthy people: Zoonosis risk from animal contact in pet shops, a systematic review of the literature. PLoS ONE 2014, 9, e89309. [CrossRef] [PubMed]

51. Day, M.J. Pet-Related Infections. Am. Fam. Physician. 2016, 94, 794-802.

52. Jacob, J.; Lorber, B. Diseases transmitted by man's best friend: The dog. Infect. Leis. 2015, 3, 111-131. [CrossRef]

53. Boseret, G.; Losson, B.; Mainil, J.G.; Thiry, E.; Saegerman, C. Zoonoses in pet birds: Review and perspectives. Vet. Res. 2013, 44, 36. [CrossRef]

54. Moro, C.V.; Chauve, C.; Zenner, L. Vectorial role of some dermanyssoid mites (Acari, Mesostigmata, Dermanyssoidea). Parasite 2005, 12, 99-109. [CrossRef]

55. Dorrestein, G.M. Bacterial and parasitic diseases of passerines. Vet. Clin. North Am. Exot. Anim. Pract. 2009, 12, 433-451. [CrossRef] [PubMed]

56. Jorn, K.S.; Thompson, K.M.; Larson, J.M.; Blair, J.E. Polly can make you sick: Pet bird-associated diseases. Cleve. Clin. J. Med. 2009, 76, 235-243. [CrossRef] [PubMed]

57. Zaman, S.B.; Sobur, M.A.; Hossain, M.J.; Pondit, A.; Khatun, M.M.; Choudhury, M.A.; Tawyabur, M.; Rahman, M.T. Molecular detection of methicillin-resistant Staphylococcus aureus (MRSA) in ornamental birds having public health significance. J. Bangladesh Agril. Univ. 2020, 18, 415-420. [CrossRef]

58. Kauffman, M.D.; LeJeune, J. European starlings (Sturnus vulgaris) challenged with Escherichia coli O157 can carry and transmit the human pathogen to cattle. Lett. Appl. Microbiol. 2011, 53, 596-601. [CrossRef] [PubMed] 
59. Belchior, E.; Barataud, D.; Ollivier, R.; Capek, I.; Laroucau, K.; De Barbeyrac, B.; Hubert, B. Psittacosis outbreak after participation in a bird fair, Western France, December 2008. Epidemiol. Infect. 2011, 139, 1637-1641. [CrossRef]

60. Vanrompay, D.; Harkinezhad, T.; Van de Walle, M.; Beeckman, D.; Van Droogenbroeck, C.; Verminnen, K.; Leten, R.; Martel, A.; Cauwerts, K. Chlamydophila psittaci transmission from pet birds to humans. Emerg. Infect. Dis. 2007, 13, 1108-1110. [CrossRef]

61. Chomel, B.B. Emerging and Re-Emerging Zoonoses of Dogs and Cats. Animals 2014, 4, 434-445. [CrossRef]

62. Burgos-Cáceres, S. Canine rabies: A looming threat to public health. Animals 2011, 1, 326-342. [CrossRef]

63. Faires, M.C.; Tater, K.C.; Weese, J.S. An investigation of methicillin-resistant Staphylococcus aureus colonization in people and pets in the same household with an infected person or infected pet. J. Am. Vet. Med. Assoc. 2009, 235, 540-543. [CrossRef]

64. Klotz, S.A.; Ianas, V.; Elliott, S.P. Cat-scratch disease. Am. Fam. Physician 2011, 83, 152-155.

65. Boylan, S. Zoonoses associated with fish. Vet. Clin. Exot. Anim. Pract. 2011, 14, 427-438. [CrossRef] [PubMed]

66. Alworth, L.C.; Harvey, S.B. IACUC issues associated with amphibian research. ILAR J. 2007, 48, $278-289$. [CrossRef] [PubMed]

67. Haenan, O.L.M.; Evans, J.J.; Berthe, F. Bacterial infections from aquatic species: Potential for and prevention of contact zoonoses. Rev. Sci. Tech. 2013, 32, 497-507. [CrossRef] [PubMed]

68. Abbot, S.L.; Janda, J.M.; Johnson, J.A.; Farmer, J.J. Vibrio and related organisms. In Manual of Clinical Microbiology, 9th ed.; Murray, P.R., Barron, E.J., Jorgensen, J.H., Landry, M.L., Pfaller, M.A., Eds.; ASM Press: Washington, DC, USA, 2007; pp. 723-733.

69. Austin, B. Vibrios as causal agents of zoonoses. Vet. Microbiol. 2010, 140, 310-317. [CrossRef] [PubMed]

70. Zhang, Q.; Dong, X.; Chen, B.; Zhang, Y.; Zu, Y.; Li, W. Zebrafish as a useful model for zoonotic Vibrio parahaemolyticus pathogenicity in fish and human. Dev. Comp. Immunol. 2016, 55, 159-168. [CrossRef] [PubMed]

71. Zereen, F.; Akter, S.; Sobur, M.A.; Hossain, M.T.; Rahman, M.T. Molecular detection of Vibrio cholerae from human stool collected from SK Hospital, Mymensingh, and their antibiogram. J. Adv. Vet. Anim. Res. 2019, 6, 451-455. [CrossRef]

72. Chen, B.Y.; Wang, C.Y.; Wang, C.L.; Fan, Y.C.; Weng, I.T.; Chou, C.H. Prevalence and persistence of Listeria monocytogenes in ready-to-eat tilapia sashimi processing plants. J. Food Prot. 2016, 79, 1898-1903. [CrossRef]

73. Kušar, D.; Zajc, U.; Jenčič, V.; Ocepek, M.; Higgins, J.; Žolnir-Dovč, M.; Pate, M. Mycobacteria in aquarium fish: Results of a 3-year survey indicate caution required in handling pet-shop fish. J. Fish Dis. 2017, 40, 773-784. [CrossRef]

74. Gauthier, D.T.; Rhodes, M.W. Mycobacteriosis in fishes: A review. Vet. J. 2009, 180, 33-47. [CrossRef]

75. Vega-López, F. Mycobacterium marinum Infection: Fish Tank Granuloma. In Hunter's Tropical Medicine and Emerging Infectious Diseases, 10th ed.; Elsevier Inc.: Amsterdam, The Netherlands, 2020; pp. 569-570.

76. Sunil, V.; Harris, A.W.; Sine, B.; Holt, A.M.; Noseworthy, A.L.; Sider, D.; Jamieson, F.B.; White, S.; Johnston, C.; Spohn, O. Investigation of a community cluster of cutaneous Mycobacterium marinum infection, an emerging zoonotic pathogen in aquaculture industry, Haliburton, Kawartha, Pine Ridge District Health Unit, Ontario, Canada, July-August 2015. Zoonoses Public Health 2019, 66, 164-168. [CrossRef]

77. Christopher, T.; Cassetty, M.D.; Miguel Sanchez, M.D. Mycobacterium marinum infection. Dermatol. Online J. 2004, 10, 21.

78. Reidarson, T. Cetacea. In Zoo and Wild Animal Medicine, 5th ed.; Fowler, M., Ed.; Saunders: St. Louis, MO, USA, 2003; pp. 442-459.

79. Dunn, L. Bacterial and mycotic diseases of cetaceans and pinnipeds. In CRC Handbook of Marine Mammal Medicine: Health, Disease, and Rehabilitation; Dierauf, L., Ed.; CRC Press: Boca Raton, FL, USA, 1990; pp. $73-87$.

80. Gauthier, D.T. Bacterial zoonoses of fishes: A review and appraisal of evidence for linkages between fish and human infections. Vet. J. 2015, 203, 27-35. [CrossRef] [PubMed]

81. Reboli, A.C.; Farrar, W.E. Erysipelothrix rhusiopathiae: An occupational pathogen. Clin. Microbiol. Rev. 1989, 2, 354-359. [CrossRef] [PubMed]

82. Wang, Q.; Chang, B.J.; Riley, T.V. Erysipelothrix rhusiopathiae. Vet. Microbiol. 2010, 140, 405-417. [CrossRef] [PubMed] 
83. Gorby, G.; Peacock, J. Erysipelothrix rhusiopathiae endocarditis: Microbiologic, epidemiologic, and clinical features of an occupational disease. Rev. Infect. Dis. 1988, 10, 317-325. [CrossRef]

84. Klauder, J.; Kramer, D.; Nicholas, L.; Kast, C.; Groskin, L.O.R.A.I.N.E. Erysipelothrix rhusiopathiae septicemia: Diagnosis and treatment: Report of fatal case of erysipeloid. JAMA 1943, 122, 938-943. [CrossRef]

85. Principe, L.; Bracco, S.; Mauri, C.; Tonolo, S.; Pini, B.; Luzzaro, F. Erysipelothrix rhusiopathiae bacteremia without endocarditis: Rapid identification from positive blood culture by MALDI-TOF mass spectrometry. A case report and literature review. Infect. Dis. Rep. 2016, 8, 6368. [CrossRef]

86. Gibello, A.; Galán-Sánchez, F.; Blanco, M.M.; Rodríguez-Iglesias, M.; Domínguez, L.; Fernández-Garayzábal, J.F. The zoonotic potential of Lactococcus garvieae: An overview on microbiology, epidemiology, virulence factors and relationship with its presence in foods. Res. Vet. Sci. 2016, 109, 59-70. [CrossRef]

87. Meyburgh, C.M.; Bragg, R.R.; Boucher, C.E. Lactococcus garvieae: An emerging bacterial pathogen of fish. Dis. Aquat. Org. 2017, 123, 67-79. [CrossRef]

88. Vendrell, D.; Balcázar, J.L.; Ruiz-Zarzuela, I.; De Blas, I.; Gironés, O.; Múzquiz, J.L. Lactococcus garvieae in fish: A review. Comp. Immunol. Microbiol. Infect. Dis. 2006, 29, 177-198. [CrossRef]

89. Malek, A.; De la Hoz, A.; Gomez-Villegas, S.I.; Nowbakht, C.; Arias, C.A. Lactococcus garvieae, an unusual pathogen in infective endocarditis: Case report and review of the literature. BMC Infect. Dis. 2019, 19, 301. [CrossRef] [PubMed]

90. Chan, J.F.W.; Woo, P.C.Y.; Teng, J.L.L.; Lau, S.K.P.; Leung, S.S.M.; Tam, F.C.C.; Yuen, K.Y. Primary infective spondylodiscitis caused by Lactococcus garvieae and a review of human L. garvieae infections. Infection 2011, 39, 259-264. [CrossRef] [PubMed]

91. Kim, J.H.; Go, J.; Cho, C.R.; Kim, J.I.; Lee, M.S.; Park, S.C. First report of human acute acalculous cholecystitis caused by the fish pathogen Lactococcus garvieae. J. Clin. Microbiol. 2013, 51, 712-714. [CrossRef] [PubMed]

92. Maekawa, S.; Yoshida, T.; Wang, P.C.; Chen, S.C. Current knowledge of nocardiosis in teleost fish. J. Fish Dis. 2018, 41, 413-419. [CrossRef]

93. Austin, B.; Austin, D. Bacterial Fish Pathogens: Diseases in Farmed and Wild Fish, 3rd ed.; Springer-Praxis: Chichester, UK, 1999.

94. Orchard, V.A. Nocardial infections of animals in New Zealand, 1976-1978. N. Z. Vet. J. 1979, 27, 159-165. [CrossRef]

95. Walton, A.M.; Libke, K.G. Nocardiosis in animals. Vet. Med. Small. Anim. Clin. 1974, 69, $1105-1107$. [PubMed]

96. Lederman, E.R.; Crum, N.F. A case series and focused review of nocardiosis: Clinical and microbiologic aspects. Medicine 2004, 83, 300-313. [CrossRef]

97. Newell, D.G.; Koopmans, M.; Verhoef, L.; Duizer, E.; Aidara-Kane, A.; Sprong, H.; Opsteegh, M.; Langelaar, M.; Threfall, J.; Scheutz, F.; et al. Food-borne diseases-The challenges of 20 years ago still persist while new ones continue to emerge. Int. J. Food Microbiol. 2010, 139, S3-S15. [CrossRef]

98. World Health Organization. WHO Estimates of the Global Burden of Foodborne Diseases: Foodborne Disease Burden Epidemiology Reference Group 2007-2015; World Health Organization: Geneva, Switzerland, 2015; p. 225.

99. Thorns, C.J. Bacterial food-borne zoonoses. Rev. Sci. Tech. 2000, 19, 226-239. [CrossRef]

100. Ievy, S.; Islam, M.S.; Sobur, M.A.; Talukder, M.; Rahman, M.B.; Khan, M.F.R.; Rahman, M.T. Molecular Detection of Avian Pathogenic Escherichia coli (APEC) for the First Time in Layer Farms in Bangladesh and Their Antibiotic Resistance Patterns. Microorganisms 2020, 8, 1021. [CrossRef]

101. Alam, S.B.; Mahmud, M.; Akter, R.; Hasan, M.; Sobur, A.; Nazir, K.H.M.; Noreddin, A.; Rahman, T.; El Zowalaty, M.E.; Rahman, M. Molecular detection of multidrug resistant Salmonella species isolated from broiler farm in Bangladesh. Pathogens 2020, 9, 201. [CrossRef] [PubMed]

102. Sobur, M.A.; Sabuj, A.A.M.; Sarker, R.; Rahman, A.M.M.T.; Kabir, S.M.L.; Rahman, M.T. Antibiotic-resistant Escherichia coli and Salmonella spp. associated with dairy cattle and farm environment having public health significance. Vet. World 2019, 12, 984-993. [CrossRef] [PubMed]

103. Treacy, J.; Jenkins, C.; Paranthaman, K.; Jorgensen, F.; Mueller-Doblies, D.; Anjum, M.; Kaindama, L.; Hartman, H.; Kirchner, M.; Carson, T.; et al. Outbreak of Shiga toxin-producing Escherichia coli O157: H7 linked to raw drinking milk resolved by rapid application of advanced pathogen characterisation methods, England, August to October 2017. Eurosurveill. 2019, 24, 1800191. [CrossRef] 
104. Yara, D.A.; Greig, D.R.; Gally, D.L.; Dallman, T.J.; Jenkins, C. Comparison of Shiga toxin-encoding bacteriophages in highly pathogenic strains of Shiga toxin-producing Escherichia coli O157: H7 in the UK. Microb. Genom. 2020, 6, e000334. [CrossRef] [PubMed]

105. Mir, R.A.; Kudva, I.T. Antibiotic-resistant Shiga toxin-producing Escherichia coli: An overview of prevalence and intervention strategies. Zoonoses Public Health 2019, 66, 1-13. [CrossRef] [PubMed]

106. Hanboonsong, Y.; Jamjanya, T.; Durst, P.B. Six-Legged Livestock: Edible Insect Farming, Collection and Marketing in Thailand; RAP Publication No. 2013/03; Food and Agriculture Organization (FAO), Regional Office for Asia and the Pacific Bangog: Bangkok, Thailand, 2013.

107. Gałęcki, R.; Sokół, R. A parasitological evaluation of edible insects and their role in the transmission of parasitic diseases to humans and animals. PLoS ONE 2019, 14, e0219303. [CrossRef] [PubMed]

108. Van Huis, A.; Van Itterbeeck, J.; Klunder, H.; Mertens, E.; Halloran, A.; Muir, G.; Vantomme, P. Edible Insects: Future Prospects for Food and Food; Food and Agriculture Organisation of the United Nations: Rome, Italy, 2013.

109. Belluco, S.; Losasso, C.; Ricci, A.; Maggioletti, M.; Alonzi, C.; Paoletti, M.G. Edible insects: A food security solution or a food safety concern? Anim. Front. 2015, 5, 25-30.

110. Belluco, S.; Losasso, C.; Maggioletti, M.; Alonzi, C.C.; Paoletti, M.G.; Ricci, A. Edible insects in a food safety and nutritional perspective: A critical review. Compr. Rev. Food Sci. Food Saf. 2013, 12, 296-313. [CrossRef]

111. Blum, M.S. The limits of entomophagy: A discretionary gourmand in a world of toxic insects. Food Insects Nerwsl. 1994, 7, 1-6.

112. Klunder, H.C.; Wolkers-Rooijackers, J.C.M.; Korpela, J.M.; Nout, M.J.R. Microbiological aspects of processing and storage of edible insects. Food Control 2012, 26, 628-631. [CrossRef]

113. Nelson, W.; Harris, B. Flies, fingers, fomites, and food. Campylo-bacteriosis in New Zealand food-associated rather than food-borne. N. Z. Med. J. 2006, 119, U2128. [PubMed]

114. Ahmad, A.; Nagaraja, T.G.; Zurek, L. Transmission of Escherichia coli O157:H7 to cattle by house flies. Prev. Vet. Med. 2007, 80, 74-81. [CrossRef] [PubMed]

115. Sobur, A.; Haque, Z.F.; Sabuj, A.A.; Ievy, S.; Rahman, A.T.; El Zowalaty, M.E.; Rahman, T. Molecular detection of multidrug and colistin-resistant Escherichia coli isolated from house flies in various environmental settings. Future Microbiol. 2019, 14, 847-858. [CrossRef] [PubMed]

116. Sobur, A.; Hasan, M.; Haque, E.; Mridul, A.I.; Noreddin, A.; El Zowalaty, M.E.; Rahman, T. Molecular Detection and Antibiotyping of Multidrug-Resistant Salmonella Isolated from Houseflies in a Fish Market. Pathogens 2019, 8, 191. [CrossRef] [PubMed]

117. Wilson, M.E.; Lorente, C.A.; Allen, J.E.; Eberhard, M.L. Gongylonema infection of the mouth in a resident of Cambridge, MA. Clin. Infect. Dis. 2001, 32, 1378-1380. [CrossRef]

118. Graczyk, T.K.; Knight, R.; Tamang, L. Mechanical transmission of human protozoan parasites by insects. Clin. Microbiol. Rev. 2005, 18, 128-132. [CrossRef]

119. World Health Organization. Emerging Zoonoses. Available online: https://www.who.int/zoonoses/emerging zoonoses/en/ (accessed on 18 July 2020).

120. Woolhouse, M.E.; Gowtage-Sequeria, S. Host range and emerging and reemerging pathogens. Emerg. Infect. Dis. 2005, 11, 1842-1847. [CrossRef]

121. Lindahl, J.F.; Grace, D. The consequences of human actions on risks for infectious diseases: A review. Infect. Ecol. Epidemiol. 2015, 5, 30048. [CrossRef]

122. Kruse, H.; Kirkemo, A.M.; Handeland, K. Wildlife as source of zoonotic infections. Emerg. Infect. Dis. 2004, 10, 2067-2072. [CrossRef]

123. Cutler, S.J.; Fooks, A.R.; Van der Poel, W.H. Public health threat of new, reemerging, and neglected zoonoses in the industrialized world. Emerg. Infect. Dis. 2010, 16, 1-7. [CrossRef]

124. Liu, Q.; Cao, L.; Zhu, X.Q. Major emerging and re-emerging zoonoses in China: A matter of global health and socioeconomic development for 1.3 billion. Int. J. Infect. Dis. 2014, 25, 65-72. [CrossRef] [PubMed]

125. Bao, M.; Pierce, G.J.; Pascual, S.; González-Muñoz, M.; Mattiucci, S.; Mladineo, I.; Cipriani, P.; Bušelić, I.; Strachan, N.J. Assessing the risk of an emerging zoonosis of worldwide concern: Anisakiasis. Sci. Rep. 2017, 7, 43699. [CrossRef] [PubMed]

126. Naicker, P.R. The impact of climate change and other factors on zoonotic diseases. Arch. Clin. Microbiol. 2011, 2, 2-7.

127. Jones, K.E.; Patel, N.G.; Levy, M.A.; Storeygard, A.; Balk, D.; Gittleman, J.L.; Daszak, P. Global trends in emerging infectious diseases. Nature 2008, 451, 990-993. [CrossRef] [PubMed] 
128. Wang, Y.; Wang, Y.; Chen, Y.; Qin, Q. Unique epidemiological and clinical features of the emerging 2019 novel coronavirus pneumonia (COVID-19) implicate special control measures. J. Med. Virol. 2020, 92, 568-576. [CrossRef]

129. Yu, X.J.; Liang, M.F.; Zhang, S.Y.; Liu, Y.; Li, J.D.; Sun, Y.L.; Zhang, L.; Zhang, Q.F.; Popov, V.L.; Li, C.; et al. Fever with thrombocytopenia associated with a novel bunyavirus in China. N. Engl. J. Med. 2011, 364, 1523-1532. [CrossRef]

130. Tran, X.C.; Yun, Y.; Le Van An, S.H.K.; Thao, N.T.P.; Man, P.K.C.; Yoo, J.R.; Heo, S.T.; Cho, N.H.; Lee, K.H. Endemic severe fever with thrombocytopenia syndrome, Vietnam. Emerg. Infect. Dis. 2019, 25, 1029-1031. [CrossRef]

131. Li, H.; Lu, Q.B.; Xing, B.; Zhang, S.F.; Liu, K.; Du, J.; Li, X.K.; Cui, N.; Yang, Z.D.; Wang, L.Y.; et al. Epidemiological and clinical features of laboratory-diagnosed severe fever with thrombocytopenia syndrome in China, 2011-2017: A prospective observational study. Lancet Infect. Dis. 2018, 18, 1127-1137. [CrossRef]

132. Bao, C.J.; Guo, X.L.; Qi, X.; Hu, J.L.; Zhou, M.H.; Varma, J.K.; Cui, L.B.; Yang, H.T.; Jiao, Y.J.; Klena, J.D.; et al. A family cluster of infections by a newly recognized bunyavirus in eastern China, 2007: Further evidence of person-to-person transmission. Clin. Infect. Dis. 2011, 53, 1208-1214. [CrossRef]

133. Park, S.J.; Kim, Y.I.; Park, A.; Kwon, H.I.; Kim, E.H.; Si, Y.J.; Song, M.S.; Lee, C.H.; Jung, K.; Shin, W.J.; et al. Ferret animal model of severe fever with thrombocytopenia syndrome phlebovirus for human lethal infection and pathogenesis. Nature Microbiol. 2019, 4, 438-446. [CrossRef]

134. Cui, F.; Cao, H.X.; Wang, L.; Zhang, S.F.; Ding, S.J.; Yu, X.J.; Yu, H. Clinical and epidemiological study on severe fever with thrombocytopenia syndrome in Yiyuan County, Shandong Province, China. Am. J. Trop. Med. Hyg. 2013, 88, 510-512. [CrossRef]

135. Takahashi, T.; Maeda, K.; Suzuki, T.; Ishido, A.; Shigeoka, T.; Tominaga, T.; Kamei, T.; Honda, M.; Ninomiya, D.; Sakai, T.; et al. The first identification and retrospective study of severe fever with thrombocytopenia syndrome in Japan. J. Infect. Dis. 2014, 209, 816-827. [CrossRef] [PubMed]

136. Kim, K.H.; Yi, J.; Kim, G.; Choi, S.J.; Jun, K.I.; Kim, N.H.; Choe, P.G.; Kim, N.J.; Lee, J.K.; Oh, M.D. Severe fever with thrombocytopenia syndrome, South Korea, 2012. Emerg. Infect. Dis. 2013, 19, 1892-1894. [CrossRef] [PubMed]

137. McMullan, L.K.; Folk, S.M.; Kelly, A.J.; MacNeil, A.; Goldsmith, C.S.; Metcalfe, M.G.; Batten, B.C.; Albariño, C.G.; Zaki, S.R.; Rollin, P.E.; et al. A new phlebovirus associated with severe febrile illness in Missouri. N. Engl. J. Med. 2012, 367, 834-841. [CrossRef] [PubMed]

138. Lee, J.; Chowell, G.; Jung, E. A dynamic compartmental model for the Middle East respiratory syndrome outbreak in the Republic of Korea: A retrospective analysis on control interventions and superspreading events. J. Theor. Biol. 2016, 408, 118-126. [CrossRef] [PubMed]

139. Hui, D.S. Epidemic and emerging coronaviruses (severe acute respiratory syndrome and Middle East respiratory syndrome). Clin. Chest Med. 2017, 38, 71-86. [CrossRef] [PubMed]

140. Perlman, S. Another decade, another coronavirus. N. Engl. J. Med. 2020, 382, 760-762. [CrossRef]

141. de Wit, E.; Feldmann, F.; Cronin, J.; Jordan, R.; Okumura, A.; Thomas, T.; Scott, D.; Cihlar, T.; Feldmann, H. Prophylactic and therapeutic remdesivir (GS-5734) treatment in the rhesus macaque model of MERS-CoV infection. Proc. Natl. Acad. Sci. USA 2020, 117, 6771-6776. [CrossRef]

142. Wernery, U.; Lau, S.K.; Woo, P.C. Middle East respiratory syndrome (MERS) coronavirus and dromedaries. Vet. J. 2017, 220, 75-79. [CrossRef]

143. Schwartz, D.A.; Graham, A.L. Potential maternal and infant outcomes from (Wuhan) coronavirus 2019-nCoV infecting pregnant women: Lessons from SARS, MERS, and other human coronavirus infections. Viruses 2020, 12, 194. [CrossRef]

144. Thompson, R.A.; Polley, L. Parasitology and one health. Int. J. Parasitol. Parasites Wildl. 2014, 3, A1-A2. [CrossRef] [PubMed]

145. Thompson, R.A. Parasite zoonoses and wildlife: One health, spillover and human activity. Int. J. Parasitol. 2013, 43, 1079-1088. [CrossRef] [PubMed]

146. Aguirre, A.A. Changing patterns of emerging zoonotic diseases in wildlife, domestic animals, and humans linked to biodiversity loss and globalization. ILAR J. 2017, 58, 315-318. [CrossRef] [PubMed]

147. Akter, M.; Islam, M.S.; Islam, M.A.; Sobur, M.A.; Jahan, M.S.; Rahman, S.; Nazir, K.N.H.; Rahman, M.T. Migratory birds as the potential source for the transmission of Aspergillus and other fungus to Bangladesh. J. Adv. Vet. Anim. Res. 2020, 7, 338-344. [CrossRef] [PubMed] 
148. Bengis, R.G.; Leighton, F.A.; Fischer, J.R.; Artois, M.; Morner, T.; Tate, C.M. The role of wildlife in emerging and re-emerging zoonoses. Rev. Sci. Tech. OIE. 2004, 23, 497-512.

149. Williams, E.S.; Yuill, T.; Artois, M.; Fischer, J.; Haigh, S.A. Emerging infectious diseases in wildlife. Rev. Sci. Tech. OIE. 2002, 21, 139-158. [CrossRef]

150. Cupertino, M.C.; Resende, M.B.; Mayer, N.A.; Carvalho, L.M.; Siqueira-Batista, R. Emerging and re-emerging human infectious diseases: A systematic review of the role of wild animals with a focus on public health impact. Asian Pac. J. Trop. Med. 2020, 13, 99-106. [CrossRef]

151. Cunningham, A.A.; Daszak, P.; Wood, J.L.N. One health, emerging infectious diseases and wildlife: Two decades of progress? Philos. Trans. R. Soc. Lond. B. Biol. Sci. 2018, 372, 20160167. [CrossRef]

152. Reperant, L.A.; Mackenzie, J.; Osterhaus, A.D.M.E. Periodic global one health threats update. One Health 2016, 2, 1-7. [CrossRef]

153. Daszak, P.; Cunningham, A.A.; Hyatt, A.D. Anthropogenic environmental change and the emergence of infectious diseases in wildlife. Acta. Trop. 2001, 78, 103-116. [CrossRef]

154. Martinez, E.; Cesário, C.; Silva, I.O.; Boere, V. Domestic dogs in rural area of fragmented atlantic forest: Potential threats to wild animals. Cienc. Rural 2013, 43, 111-222. [CrossRef]

155. Fehr, A.R.; Perlman, S. Coronaviruses: An overview of their replication and pathogenesis. In Coronaviruses; Humana Press: Totowa, NJ, USA, 2015; Volume 1282, pp. 1-23.

156. Li, G.; Fan, Y.; Lai, Y.; Han, T.; Li, Z.; Zhou, P.; Pan, P.; Wang, W.; Hu, D.; Liu, X.; et al. Coronavirus infections and immune responses. J. Med. Virol. 2020, 92, 424-432. [CrossRef] [PubMed]

157. Lam, T.T.Y.; Jia, N.; Zhang, Y.W.; Shum, M.H.H.; Jiang, J.F.; Zhu, H.C.; Tong, Y.G.; Shi, Y.X.; Ni, X.B.; Liao, Y.S.; et al. Identifying SARS-CoV-2-related coronaviruses in Malayan pangolins. Nature 2020, 583, 282-285. [CrossRef] [PubMed]

158. Channappanavar, R.; Perlman, S. Pathogenic human coronavirus infections: Causes and consequences of cytokine storm and immunopathology. Semin. Immunopathol. 2017, 39, 529-539. [CrossRef] [PubMed]

159. Rahman, T.; Sobur, A.; Islam, S.; Toniolo, A.; Nazir, K.N.H. Is the COVID-19 pandemic masking dengue epidemic in Bangladesh? J. Adv. Vet. Anim. Res. 2020, 7, 218-219. [CrossRef]

160. World Health Organization. Coronavirus disease (COVID-19) Weekly Epidemiological Update and Weekly Operational Update. Available online: https://www.who.int/docs/default-source/coronaviruse/situationreports/20200831-weekly-epi-update-3.pdf?sfvrsn=d7032a2a_4 (accessed on 31 August 2020).

161. Corman, V.M.; Baldwin, H.J.; Tateno, A.F.; Zerbinati, R.M.; Annan, A.; Owusu, M.; Nkrumah, E.E.; Maganga, G.D.; Oppong, S.; Adu-Sarkodie, Y.; et al. Evidence for an ancestral association of human coronavirus 229E with bats. J. Virol. 2015, 89, 11858-11870. [CrossRef]

162. Tao, Y.; Shi, M.; Chommanard, C.; Queen, K.; Zhang, J.; Markotter, W.; Kuzmin, I.V.; Holmes, E.C.; Tong, S. Surveillance of bat coronaviruses in Kenya identifies relatives of human coronaviruses NL63 and 229E and their recombination history. J. Virol. 2017, 91, e01953-16. [CrossRef]

163. Corman, V.M.; Eckerle, I.; Memish, Z.A.; Liljander, A.M.; Dijkman, R.; Jonsdottir, H.; Ngeiywa, K.J.J.; Kamau, E.; Younan, M.; Al Masri, M.; et al. Link of a ubiquitous human coronavirus to dromedary camels. Proc. Natl. Acad. Sci. USA 2016, 113, 9864-9869. [CrossRef]

164. Hamre, D.; Procknow, J.J. A new virus isolated from the human respiratory tract. Proc. Soc. Exp. Biol. Med. 1966, 121, 190-193. [CrossRef]

165. McIntosh, K.; Dees, J.H.; Becker, W.B.; Kapikian, A.Z.; Chanock, R.M. Recovery in tracheal organ cultures of novel viruses from patients with respiratory disease. Proc. Natl. Acad. Sci. USA 1967, 57, 933-940. [CrossRef]

166. Tyrrell, D.A.J.; Cohen, S.; Schilarb, J.E. Signs and symptoms in common colds. Epidemiol. Infect. 1993, 111, 143-156. [CrossRef]

167. Bradburne, A.F.; Bynoe, M.L.; Tyrrell, D.A. Effects of a "new" human respiratory virus in volunteers. Br. Med. J. 1967, 3, 767-769. [CrossRef] [PubMed]

168. Donaldson, E.F.; Haskew, A.N.; Gates, J.E.; Huynh, J.; Moore, C.J.; Frieman, M.B. Metagenomic analysis of the viromes of three North American bat species: Viral diversity among different bat species that share a common habitat. J. Virol. 2010, 84, 13004-13018. [CrossRef]

169. Huynh, J.; Li, S.; Yount, B.; Smith, A.; Sturges, L.; Olsen, J.C.; Nagel, J.; Johnson, J.B.; Agnihothram, S.; Gates, J.E.; et al. Evidence supporting a zoonotic origin of human coronavirus strain NL63. J. Virol. 2012, 86, 12816-12825. [CrossRef] [PubMed] 
170. Van Der Hoek, L.; Pyrc, K.; Jebbink, M.F.; Vermeulen-Oost, W.; Berkhout, R.J.; Wolthers, K.C.; Wertheim-van Dillen, P.M.; Kaandorp, J.; Spaargaren, J.; Berkhout, B. Identification of a new human coronavirus. Nat. Med. 2004, 10, 368-373. [CrossRef] [PubMed]

171. Abdul-Rasool, S.; Fielding, B.C. Understanding human coronavirus HCoV-NL63. Open Virol. J. 2010, 4, 76-84. [CrossRef] [PubMed]

172. Fouchier, R.A.; Hartwig, N.G.; Bestebroer, T.M.; Niemeyer, B.; De Jong, J.C.; Simon, J.H.; Osterhaus, A.D. A previously undescribed coronavirus associated with respiratory disease in humans. Proc. Natl. Acad. Sci. USA 2004, 101, 6212-6216. [CrossRef]

173. Van Der Hoek, L.; Sure, K.; Ihorst, G.; Stang, A.; Pyrc, K.; Jebbink, M.F.; Petersen, G.; Forster, J.; Berkhout, B.; Überla, K. Croup is associated with the novel coronavirus NL63. PLoS Med. 2005, 2, e240. [CrossRef]

174. Cui, J.; Li, F.; Shi, Z.L. Origin and evolution of pathogenic coronaviruses. Nat. Rev. Microbiol. 2019, 17, 181-192. [CrossRef]

175. Woo, P.C.; Lau, S.K.; Chu, C.M.; Chan, K.H.; Tsoi, H.W.; Huang, Y.; Wong, B.H.; Poon, R.W.; Cai, J.J.; Luk, W.K.; et al. Characterization and complete genome sequence of a novel coronavirus, coronavirus HKU1, from patients with pneumonia. J. Virol. 2005, 79, 884-895. [CrossRef]

176. Lau, S.K.; Woo, P.C.; Yip, C.C.; Tse, H.; Tsoi, H.W.; Cheng, V.C.; Lee, P.; Tang, B.S.; Cheung, C.H.; Lee, R.A.; et al. Coronavirus HKU1 and other coronavirus infections in Hong Kong. J. Clin. Microbiol. 2006, 44, 2063-2071. [CrossRef] [PubMed]

177. Centers for Disease Control and Prevention (CDC). Prevalence of IgG antibody to SARS-associated coronavirus in animal traders-Guangdong Province, China, 2003. MMWR. Morb. Mortal. Wkly. Rep. 2003, 52, 986-987.

178. Guan, Y.; Zheng, B.J.; He, Y.Q.; Liu, X.L.; Zhuang, Z.X.; Cheung, C.L.; Luo, S.W.; Li, P.H.; Zhang, L.J.; Guan, Y.J.; et al. Isolation and characterization of viruses related to the SARS coronavirus from animals in southern China. Science 2003, 302, 276-278. [CrossRef] [PubMed]

179. Poon, L.L.; Chu, D.K.; Chan, K.H.; Wong, O.K.; Ellis, T.M.; Leung, Y.H.C.; Lau, S.K.; Woo, P.C.Y.; Suen, K.Y.; Yuen, K.Y.; et al. Identification of a novel coronavirus in bats. J. Virol. 2005, 79, 2001-2009. [CrossRef] [PubMed]

180. Tu, C.; Crameri, G.; Kong, X.; Chen, J.; Sun, Y.; Yu, M.; Xiang, H.; Xia, X.; Liu, S.; Ren, T.; et al. Antibodies to SARS coronavirus in civets. Emerg. Infect. Dis. 2004, 10, 2244-2248. [CrossRef]

181. Lau, S.K.; Woo, P.C.; Li, K.S.; Huang, Y.; Tsoi, H.W.; Wong, B.H.; Wong, S.S.; Leung, S.Y.; Chan, K.H.; Yuen, K.Y. Severe acute respiratory syndrome coronavirus-like virus in Chinese horseshoe bats. Proc. Natl. Acad. Sci. USA 2005, 102, 14040-14045. [CrossRef]

182. Li, W.; Shi, Z.; Yu, M.; Ren, W.; Smith, C.; Epstein, J.H.; Wang, H.; Crameri, G.; Hu, Z.; Zhang, H.; et al. Bats are natural reservoirs of SARS-like coronaviruses. Science 2005, 310, 676-679. [CrossRef]

183. Ge, X.Y.; Li, J.L.; Yang, X.L.; Chmura, A.A.; Zhu, G.; Epstein, J.H.; Mazet, J.K.; Hu, B.; Zhang, W.; Peng, C.; et al. Isolation and characterization of a bat SARS-like coronavirus that uses the ACE2 receptor. Nature 2013, 503, 535-538. [CrossRef]

184. van Boheemen, S.; de Graaf, M.; Lauber, C.; Bestebroer, T.M.; Raj, V.S.; Zaki, A.M.; Osterhaus, A.D.; Haagmans, B.L.; Gorbalenya, A.E.; Snijder, E.J.; et al. Genomic characterization of a newly discovered coronavirus associated with acute respiratory distress syndrome in humans. MBio 2012, 3, e00473-12. [CrossRef] [PubMed]

185. Cotten, M.; Lam, T.T.; Watson, S.J.; Palser, A.L.; Petrova, V.; Grant, P.; Pybus, O.G.; Rambaut, A.; Guan, Y.; Pillay, D.; et al. Full-genome deep sequencing and phylogenetic analysis of novel human betacoronavirus. Emerg. Infect. Dis. 2013, 19, 736-742. [CrossRef] [PubMed]

186. Annan, A.; Baldwin, H.J.; Corman, V.M.; Klose, S.M.; Owusu, M.; Nkrumah, E.E.; Badu, E.K.; Anti, P.; Agbenyega, O.; Meyer, B.; et al. Human betacoronavirus 2c EMC/2012-related viruses in bats, Ghana and Europe. Emerg. Infect. Dis. 2013, 19, 456-459. [CrossRef] [PubMed]

187. Lau, S.K.; Zhang, L.; Luk, H.K.; Xiong, L.; Peng, X.; Li, K.S.; He, X.; Zhao, P.S.H.; Fan, R.Y.; Wong, A.C.; et al. Receptor usage of a novel bat lineage $C$ betacoronavirus reveals evolution of Middle East respiratory syndrome-related coronavirus spike proteins for human dipeptidyl peptidase 4 binding. J. Infect. Dis. 2018, 218, 197-207. [CrossRef] [PubMed]

188. Luo, C.M.; Wang, N.; Yang, X.L.; Liu, H.Z.; Zhang, W.; Li, B.; Hu, B.; Peng, C.; Geng, Q.B.; Zhu, G.J.; et al. Discovery of novel bat coronaviruses in South China that use the same receptor as Middle East respiratory syndrome coronavirus. J. Virol. 2018, 92, e00116-18. [CrossRef] [PubMed] 
189. Reusken, C.B.; Haagmans, B.L.; Müller, M.A.; Gutierrez, C.; Godeke, G.J.; Meyer, B.; Muth, D.; Raj, V.S.; Smits-De Vries, L.; Corman, V.M.; et al. Middle East respiratory syndrome coronavirus neutralising serum antibodies in dromedary camels: A comparative serological study. Lancet Infect. Dis. 2013, 13, 859-866. [CrossRef]

190. Chan, J.F.; Lau, S.K.; To, K.K.; Cheng, V.C.; Woo, P.C.; Yuen, K.Y. Middle East respiratory syndrome coronavirus: Another zoonotic betacoronavirus causing SARS-like disease. Clin. Microbiol. Rev. 2015, 28, 465-522. [CrossRef]

191. Raj, V.S.; Farag, E.A.; Reusken, C.B.; Lamers, M.M.; Pas, S.D.; Voermans, J.; Smits, S.L.; Osterhaus, A.D.; Al-Mawlawi, N.; Al-Romaihi, H.E.; et al. Isolation of MERS coronavirus from a dromedary camel, Qatar, 2014. Emerg. Infect. Dis. 2014, 20, 1339-1342. [CrossRef]

192. Adney, D.R.; Letko, M.; Ragan, I.K.; Scott, D.; van Doremalen, N.; Bowen, R.A.; Munster, V.J. Bactrian camels shed large quantities of Middle East respiratory syndrome coronavirus (MERS-CoV) after experimental infection. Emerg. Microbes Infect. 2019, 8, 717-723. [CrossRef]

193. Samara, E.M.; Abdoun, K.A. Concerns about misinterpretation of recent scientific data implicating dromedary camels in epidemiology of Middle East respiratory syndrome (MERS). MBio 2014, 5, e01430-14. [CrossRef]

194. Hilgenfeld, R.; Peiris, M. From SARS to MERS: 10 years of research on highly pathogenic human coronaviruses. Antivir. Res. 2013, 100, 286-295. [CrossRef]

195. Gao, H.; Yao, H.; Yang, S.; Li, L. From SARS to MERS: Evidence and speculation. Front. Med. 2016, 10, 377-382. [CrossRef]

196. Coleman, C.M.; Frieman, M.B. Emergence of the Middle East respiratory syndrome coronavirus. PLoS Pathog. 2013, 9, e1003595. [CrossRef] [PubMed]

197. Zhou, P.; Yang, X.L.; Wang, X.G.; Hu, B.; Zhang, L.; Zhang, W.; Si, H.R.; Zhu, Y.; Li, B.; Huang, C.L.; et al. A pneumonia outbreak associated with a new coronavirus of probable bat origin. Nature 2020, 579, 270-273. [CrossRef] [PubMed]

198. Huang, C.; Wang, Y.; Li, X.; Ren, L.; Zhao, J.; Hu, Y.; Zhang, L.; Fan, G.; Xu, J.; Gu, X.; et al. Clinical features of patients infected with 2019 novel coronavirus in Wuhan, China. Lancet 2020, 395, 497-506. [CrossRef]

199. Islam, M.S.; Sobur, M.A.; Akter, M.; Nazir, K.N.H.; Toniolo, A.; Rahman, M.T. Coronavirus Disease 2019 (COVID-19) pandemic, lessons to be learned! J. Adv. Vet. Anim. Res. 2020, 7, 260-280. [CrossRef]

200. Hossain, M.G.; Akter, S.; Saha, S. SARS-CoV-2 host diversity: An update of natural infections and experimental evidences. J. Microbiol. Immunol. Infect. 2020. [CrossRef] [PubMed]

201. Maudlin, I.; Eisler, M.C.; Welburn, S.C. Neglected and endemic zoonoses. Philos. Trans. R. SocLond. B. Biol. Sci. 2009, 364, 2777-2787. [CrossRef]

202. World Health Organization. ICONZ_Integrated Control of Neglected Zoonotic Diseases E United Kingdom. Dept for International Development Research in Use. The Control of Neglected Zoonotic Diseases: Community Based Interventions for NZDs Prevention and Control: Report of the Third Conference Organized with ICONZ, DFID-RiU, SOS, EU, TDR and FAO with the Participation of ILRI and OIE: 23-24 November 2010; World Health Organization; WHO Heaquarters: Geneva, Switzerland, 2011.

203. World Health Organization. World Health Assembly Adopts Resolution on Neglected Tropical Diseases. Available online: https://www.who.int/neglected_diseases/WHA_66_seventh_day_resolution_adopted/en/ (accessed on 18 July 2020).

204. Mrzljak, A.; Novak, R.; Pandak, N.; Tabain, I.; Franusic, L.; Barbic, L.; Bogdanic, M.; Savic, V.; Mikulic, D.; Pavicic-Saric, J.; et al. Emerging and neglected zoonoses in transplant population. World J. Transplant. 2020, 10,47-63. [CrossRef]

205. Elelu, N.; Aiyedun, J.O.; Mohammed, I.G.; Oludairo, O.O.; Odetokun, I.A.; Mohammed, K.M.; Bale, J.O.; Nuru, S. Neglected zoonotic diseases in Nigeria: Role of the public health veterinarian. Pan Afr. Med. J. 2019, 32, 36. [CrossRef]

206. World Health Organization. Neglected Tropical Diseases. Available online: https://www.who.int/neglected_ diseases/zoonoses/en/ (accessed on 18 July 2020).

207. Meslin, F.X. Impact of zoonoses on human health. Vet. Ital. 2006, 42, 369-379.

208. ARÁMBULO III, P.V.; Thakur, A.S. Impact of zoonoses in tropical America. Ann. N. Y. Acad. Sci. 1992, 653, 6-18. [CrossRef]

209. Cascio, A.; Bosilkovski, M.; Rodriguez-Morales, A.J.; Pappas, G. The socio-ecology of zoonotic infections. Clin. Microbiol. Infect. 2011, 17, 336-342. [CrossRef] [PubMed] 
210. Bennett, R.; IJpelaar, J. Updated estimates of the costs associated with thirty four endemic livestock diseases in Great Britain: A note. J. Agric. Econ. 2005, 56, 135-144. [CrossRef]

211. Martins, S.; Häsler, B.; Rushton, J. Economic Aspects of Zoonoses: Impact of Zoonoses on the Food Industry. In Zoonoses-Infections Affecting Humans and Animals; Sing, A., Ed.; Springer: Dordrecht, The Netherlands, 2015; pp. 1107-1126.

212. World Bank. People, Pathogens and Our Planet: The Economics of One Health; World Bank: Washington, DC, USA, 2012. Available online: http://documents.worldbank.org/curated/en/2012/06/16360943/peoplepathogensplanet-economics-one-health (accessed on 20 July 2020).

213. MARSH Report. The Economic and Social Impact of Emerging Infectious Disease. Available online: http://www.healthcare.philips.com/main/shared/assets/documents/bioshield/ ecoandsocialimpactofemerginginfectiousdisease_111208.pdf (accessed on 24 August 2020).

214. Keusch, G.T.; Pappaioanou, M.; Gonzalez, M.C.; Scott, K.A.; Tsai, P. National Research Council. Sustaining Global Surveillance and response to emerging zoonotic diseases. In Committee on Achieving Sustainable Global Capacity for Surveillance and Response to Emerging Diseases of Zoonotic Origin; The National Academies Press: Washington, DC, USA, 2009.

215. Rassy, D.; Smith, R.D. The economic impact of H1N1 on Mexico's tourist and pork sectors. Health Econ. 2013, 22, 824-834. [CrossRef] [PubMed]

216. Wright, C. A good example of successful crisis management: The avian influenza outbreak in Chile-What actually happened and what can be learned from their experience. Poult. Int. 2004, 43, 34-39.

217. Burroughs, T.; Knobler, S.; Lederberg, J. The emergence of zoonotic diseases: Understanding the impact on animal and human health: Workshop summary. In the Emergence of Zoonotic Diseases: Understanding the Impact on Animal and Human Health: Workshop Summary; Burroughs, T., Knobler, S., Lederberg, J., Eds.; National Academy Press: Washington, DC, USA, 2002.

218. Mitura, V.; Di Piétro, L. Canada's beef cattle sector and the impact of BSE on farm family income 2000-2003. In Agriculture and Rural Working Paper Series Working Paper No. 69; Canada Statistics, Agricultural Division: Ottawa, ON, Canada, 2004.

219. Coffey, B.; Mintert, J.; Fox, S.; Schroeder, T.; Valentin, L. Economic Impact of BSE on the US Beef Industry: Product Value Losses, Regulatory Costs and Consumer Reactions; Kansas State University: Kansas, MO, USA, 2005.

220. Food and Agriculture Organization of the United Nations (FAO). The Monetary Impact of Zoonotic Diseases on Society, Evidence from Three Zoonoses in Kenya. Available online: http://www.fao.org/3/i8968en/I8968EN.pdf (accessed on 24 August 2020).

221. Samartino, L.E. Brucellosis in Argentina. Vet. Microbiol. 2002, 90, 71-80. [CrossRef]

222. Ajogi, I. Settling the nomads in Wase and Wawa-Zange grazing reserves in the Sudan savannah zone of Nigeria IV: Strategies for the control of bovine brucellosis. Niger. Vet. J. 1998, 19, 40-48.

223. Ozili, P.K.; Arun, T. Spillover of COVID-19: Impact on the Global Economy. Available at SSRN 3562570. 2020. Available online: http://dx.doi.org/10.2139/ssrn.3562570 (accessed on 24 August 2020).

224. The World Bank. The Global Economic Outlook during the COVID-19 Pandemic: A Changed World. Available online: https:/www.worldbank.org/en/news/feature/2020/06/08/the-global-economic-outlookduring-the-covid-19-pandemic-a-changed-world (accessed on 24 August 2020).

225. Bidaisee, S.; Macpherson, C.N. Zoonoses and one health: A review of the literature. J. Parasitol. Res. 2014, 2014, 874345. [CrossRef]

226. Al-Tayib, O.A. An overview of the most significant zoonotic viral pathogens transmitted from animal to human in Saudi Arabia. Pathogens 2019, 8, 25. [CrossRef]

227. Ng, V.; Sargeant, J.M. A quantitative approach to the prioritization of zoonotic diseases in North America: A health professionals' perspective. PLoS ONE 2013, 8, e72172. [CrossRef]

228. Aenishaenslin, C.; Hongoh, V.; Cissé, H.D.; Hoen, A.G.; Samoura, K.; Michel, P.; Waaub, J.P.; Bélanger, D. Multi-criteria decision analysis as an innovative approach to managing zoonoses: Results from a study on Lyme disease in Canada. BMC Public Health 2013, 13, 897. [CrossRef]

229. Van der Giessen, J.W.B.; van De Giessen, A.W.; Braks, M.A.H. Emerging Zoonoses: Early Warning and Surveillance in the Netherlands; RIVM: Utrecht, The Netherlands, 2010.

230. Chomel, B.B. Control and prevention of emerging parasitic zoonoses. Int. J. Parasitol. 2008, 38, $1211-1217$. [CrossRef] [PubMed] 
231. Hassell, J.M.; Begon, M.; Ward, M.J.; Fèvre, E.M. Urbanization and disease emergence: Dynamics at the wildlife-livestock-human interface. Trends Ecol. Evol. 2017, 32, 55-67. [CrossRef] [PubMed]

232. Rahman, M.T. Chikungunya virus infection in developing countries-What should we do? J. Adv. Vet. Anim. Res. 2017, 4, 125-131. [CrossRef]

233. Murphy, S.C.; Negron, M.E.; Pieracci, E.G.; Deressa, A.; Bekele, W.; Regassa, F.; Wassie, B.A.; Afera, B.; Hajito, K.W.; Walelign, E.; et al. One Health collaborations for zoonotic disease control in Ethiopia. Rev. Sci. Tech. 2019, 38, 51-60. [CrossRef]

234. Pal, M.; Gebrezabiher, W.; Rahman, M.T. The roles of veterinary, medical and environmental professionals to achieve One Health. J. Adv. Vet. Anim. Res. 2014, 1, 148-155. [CrossRef]

235. Gibbs, E.P.J. The evolution of One Health: A decade of progress and challenges for the future. Vet. Rec. 2014, 174, 85-91. [CrossRef]

236. Dahal, R.; Kahn, L. Zoonotic diseases and one health approach. Epidemiology 2014, 10. [CrossRef]

237. One Health. One Health Commission. Available online: http://www.onehealthcommission.org/ (accessed on 19 July 2020).

238. Okello, A.L.; Gibbs, E.P.J.; Vandersmissen, A.; Welburn, S.C. One Health and the neglected zoonoses: Turning rhetoric into reality. Vet. Rec. 2011, 169, 281-285. [CrossRef]

239. CDC-One health. One Health Zoonotic Disease Prioritization (OHZDP). Available online: https://www.cdc. gov/onehealth/what-we-do/zoonotic-disease-prioritization/index.html (accessed on 19 July 2020).

240. Pulliam, J.R.; Epstein, J.H.; Dushoff, J.; Rahman, S.A.; Bunning, M.; Jamaluddin, A.A.; Hyatt, A.D.; Field, H.E.; Dobson, A.P.; Daszak, P. Agricultural intensification, priming for persistence and the emergence of Nipah virus: A lethal bat-borne zoonosis. J. R. Soc. Interface 2012, 9, 89-101. [CrossRef]

241. Cardiff, R.D.; Ward, J.M.; Barthold, S.W. 'One medicine-One pathology': Are veterinary and human pathology prepared? Lab. Invest. 2008, 88, 18-26. [CrossRef]

242. Pieracci, E.G.; Hall, A.J.; Gharpure, R.; Haile, A.; Walelign, E.; Deressa, A.; Bahiru, G.; Kibebe, M.; Walke, H.; Belay, E. Prioritizing zoonotic diseases in Ethiopia using a one health approach. One Health 2016, 2, 131-135. [CrossRef] [PubMed]

(C) 2020 by the authors. Licensee MDPI, Basel, Switzerland. This article is an open access article distributed under the terms and conditions of the Creative Commons Attribution (CC BY) license (http://creativecommons.org/licenses/by/4.0/). 